\title{
Pathways to positive scenarios for the Amazon forest in Pará state, Brazil
}

\author{
Juliana Siqueira-Gay', Aurora Miho Yanai ${ }^{2}$,Janeth Lessmann ${ }^{3}$,Ana Carolina M. Pessôa ${ }^{4}$, Danilo Borja ${ }^{5}$, \\ Moara Canova ${ }^{6}$ \& Rafael Cabral Borges ${ }^{7,8^{*}}$ (i) \\ ${ }^{1}$ Universidade de São Paulo, Escola Politécnica, Av. Prof. Mello Moraes, 2373, CEP 05508-900, Butantã, São \\ Paulo, SP, Brasil \\ ${ }^{2}$ Instituto Nacional de Pesquisas da Amazônia, Coordenação de Dinâmica Ambiental, Av. André Araújo, 2936, \\ CEP 69067-375, Manaus, AM, Brasil \\ ${ }^{3}$ Pontificia Universidad Católica de Chile, Facultad de Ciencias Biológicas, Departamento de Ecología, \\ Alameda 340, CEP 8331150, Santiago, Chile \\ ${ }^{4}$ Instituto Nacional de Pesquisas Espaciais, Divisão de Sensoriamento Remoto, Av. Astronautas, 1758, CEP \\ 12227-010, São José dos Campos, SP, Brasil \\ ${ }^{5}$ University of Calgary, Department of Geography, 2500 University Drive NW, T2N 4N4, Calgary, Alberta, \\ Canada \\ ${ }^{6}$ Universidade Estadual de Campinas, Instituto de Filosofia e Ciências Humanas, Rua Carlos Gomes, CEP \\ 13083-970, São Paulo, SP, Brasil \\ ${ }^{7}$ Universidade Federal do Pará, Instituto de Ciências Biológicas Pós-Graduação em Zoologia, Rua Augusto \\ Correa, 1, CEP, 66075-110, Belém, Pará, Brasil \\ ${ }^{8}$ Instituto Tecnológico Vale, Rua Boaventura da Silva, 955, CEP 65055-090, Belém, Pará, Brasil \\ *Corresponding author: Rafael C.Borges, e-mail: rcabralsan@gmail.com
}

SIQUEIRA-GAY, J., YANAI, A. M., LESSMANN, J., PESSÔA, A. C. M., BORJA, D., CANOVA, M., BORGES, R. C. Pathways to positive scenarios for the Amazon forest in Pará state, Brazil. Biota Neotropica. 20(suppl. 1): e20190905. https://doi.org/10.1590/1676-0611-BN-2019-0905

\begin{abstract}
Infrastructure projects and agriculture expansion are increasingly threatening forest conservation in Pará state (Brazil). It becomes necessary to address the implications of these activities on the Amazon complex socioecological system, considering both material and non-material aspects of Nature's Contributions to People (NCP). Multiple studies developed future scenarios for the Amazon, but only a few have focused on discussing positive futures derived from policies and interventions based on conservation and human well-being. Here, we aim at understanding the drivers of forest cover change to produce positive scenarios for the future of the Amazon forest in Pará state. By using the Intergovernmental Science-Policy Platform on Biodiversity and Ecosystem Services (IPBES) conceptual framework, we identified as direct drivers of forest cover change: (i) roads construction; (ii) forest degradation; (iii) hydropower projects; (iv) urban expansion; (v) agriculture and pasture expansion; (vi) rural land occupation; (vii) mining; (viii) climate change. As indirect drivers we identified: (i) energy demand; (ii) population growth; (iii) land prices; (iv) commodity demand; (v) consumption behavior. The development of conservation strategies in the borders of deforested areas is needed given the high demand for Nature's Contributions to People supply. We also propose policies to address the main drivers of forest cover change, influencing land management and consumption behavior in the state. At last, we envision future positive scenarios that would emerge from policy applications and sustainable actions. Based on our study, we discuss the importance of social learning for developing pathways leading to positive futures that consider the integrity and development of both ecological and social systems.
\end{abstract}

Keywords: Deforestation, Biodiversity, Ecosystem services, Forest degradation, Conceptual framework, IPBES. 
Siqueira-Gay J. et al.

\title{
Caminhos de cenários positivos para a floresta Amazônica no estado do Pará, Brasil.
}

\begin{abstract}
Resumo: Projetos de infraestrutura e expansão agrícola estão cada vez mais ameaçando a conservação florestal no estado do Pará (Brasil). Assim, torna-se necessário abordar as implicações dessas atividades no complexo sistema sócio ecológico da Amazônia, considerando aspectos materiais e não materiais das Contribuições da Natureza para as Pessoas (NCP). Vários estudos desenvolveram cenários para o futuro da floresta Amazônica, porém poucos foram aqueles focados em discutir futuros positivos, derivados da aplicação de políticas e de intervenções baseadas em estratégias de conservação e de sustentabilidade. Neste trabalho buscamos entender os principais fatores determinantes da mudança na cobertura florestal no estado do Pará, de forma a produzir cenários positivos para o futuro da floresta amazônica nesse estado. A partir da estrutura conceitual proposta pela Plataforma Intergovernamental sobre Biodiversidade e Serviços Ecossistêmicos (IPBES) identificamos as principais pressões diretas e indiretas que influenciam na perda de floresta no estado, e os articulamos em um modelo conceitual. As pressões diretas identificadas foram: (i) construção de estradas; (ii) degradação florestal; (iii) projetos para construção de hidrelétricas; (iv) expansão urbana; (v) expansão da agricultura e da pecuária; (vi) ocupação de terras rurais; (vii) mineração; (viii) mudanças climáticas. As pressões indiretas identificadas foram: (i) demanda por energia; (ii) crescimento populacional; (iii) preços da terra; (iv) demanda por commodities; (v) hábitos de consumo. Assim, evidenciamos a importância do desenvolvimento de estratégias de conservação nas áreas de fronteiras de desmatamento devido à alta demanda e oferta por Contribuições da Natureza para as Pessoas (NCPs). Foram propostas políticas para influenciar mudança no gerenciamento da terra e nos hábitos de consumo de forma a abordar os principais fatores de mudança da cobertura florestal no estado. Por fim, nós construímos cenários futuros positivos que emergiriam da aplicação de políticas e ações voltadas para sustentabilidade da natureza e dos serviços ecossistêmicos. Com base em nossa avaliação, enfatizamos a importância do aprendizado social para que possam ser discutidos os caminhos que levam a futuros positivos, que consideram a integridade e o desenvolvimento tanto dos sistemas sociais quanto dos sistemas ecológicos.
\end{abstract}

Palavras-chave: Desmatamento, Biodiversidade, Serviços ecossistêmicos, Degradação florestal, Modelo conceitual, IPBES.

\section{Introduction}

The Amazon rainforest is one of the most biodiverse regions on Earth (Laurance et al. 2002). This region is key to sustain life, mitigating climate change by sinking and stocking carbon (Pütz et al. 2014). Its ecological processes and systems also represent a major element to sustain the production of goods relevant to human wellbeing, such as food, minerals, and timber (Strand et al. 2018). Furthermore, it is a culturally rich region, home to traditional and indigenous communities. These communities maintain a unique knowledge, that is instrumental for forest conservation (Agrawal 1995).

Drivers of forest cover change, such as infrastructure projects and agriculture expansion, largely affect the provision of ecological processes and functions, ultimately hindering the maintenance of Amazonian ecosystem integrity, at local, regional, and global scales. The Pará state (Brazilian Eastern Amazon) presented the highest forest loss of the Brazilian Amazon states in 2019 (3,862 km²), with an increasing rate of $41 \%$ when compared to 2018 (Brazil, INPE, 2019). This rate followed a history of anthropogenic occupancy (last 50 years) mainly caused by anthropogenic actions such as road building (Fearsnide 2008, Soares-Filho et al. 2004), hydropower projects (Athayde et al. 2019), mining (Lobo et al. 2018, Sonter et al. 2017, Souza-Filho et al. 2016) and agriculture expansion (Brown et al. 2016, Simmons et al. 2007, Simon \& Garagorry 2005), which challenges forest conservation within the state.

In response to these pressures, the Brazilian government has proposed a series of policies, such as PPCDAm (Portuguese acronym for: Action Plan for the Prevention and Control of Deforestation in the Legal Amazon), that includes the creation of new protected areas (Herrera et al. 2019), and the soy and beef moratorium (Gibbs et al. 2015, Boucher et al. 2013). However, the clash between multiple worldviews and understandings of environmental governance and global change has challenged the implementation of these socioenvironmental policies (Rodrigues-Filho et al. 2015, Carvalho et al. 2019) and the current trends of increasing deforestation, mainly in response to political actions, suggests further degradation of the Amazon forest (West et al. 2019, Armenteras et al. 2019).

The Brazilian Amazon, a very complex socio-ecological system, represents an arena for the interplay between scientific and local representations (e.g., oral accounts, metaphors, symbols, and values) (Rajão 2013). Although multiple factors are often neglected by studies of forest governance, including the cultural and relational values that forest have to local people, these aspects are of primary importance for the development of protection, conservation and sustainability policies (Chan et al. 2018). Therefore, the region needs a shift from traditional ways of building scenarios and policies towards a more integrative and nature-centered pathway for building a sustainable future for the Amazon forest.

The Intergovernmental Science-Policy Platform on Biodiversity and Ecosystem Services (IPBES) proposed a novel conceptual framework that gauge the multiple factors influencing and controlling environmental change (Díaz et al. 2015). One of the key elements of this framework is the notion of Nature's Contributions to People (NCP). 
As presented (Díaz et al. 2018, p. 270), the NCP concept has two main features: "first, the NCP approach recognizes the central and pervasive role that culture plays in defining all links between people and nature". "Second, the use of NCP elevates, emphasizes, and operationalizes the role of indigenous and local knowledge in understanding nature's contribution to people."

As such, IPBES contribution to environmental governance is twofold. Firstly, the NCP framework builds on a participatory process through reviews and workshops conducted with stakeholders across the globe. Secondly, the framework not only draws on scientific knowledge from various streams (e.g. natural, economic, social and engineering) but also developed by integrating knowledge produced by a broad spectrum of stakeholders, such as indigenous and local people, nongovernmental organizations (NGOs), and governments (Díaz et al. 2015). The IPBES new understanding of human-nature relationships has motivated the production of the Nature Futures Framework (NFF), which allows multiple actors to create policies and practices considering different views on nature and values. This framework also represents a tool to develop positive narratives to push forward pro-environment behavior and to discuss potential actions towards meeting global environmental goals (Rosa et al. 2017, Lundquist et al. 2017).

Previous studies conducted in the Amazon have proposed future projections considering new infrastructure construction involving different approaches to model forest cover change close to roads, infrastructure projects and protected areas (Laurance et al., 2001; Rosa et al., 2013; Soares-Filho et al., 2006). However, few of them provide an integrative positive future with different views and values of Amazon and propose policies targeting reducing forest cover change. Thus, we aim at providing an understanding of the drivers of forest cover change in Pará state by applying the IPBES framework for proposing ways to shift current trends towards positive scenarios. We identified the main drivers causing forest loss to propose policies that tackle it in Pará state. We seek mainstreaming knowledge and values in the decision-making of tropical forest conservation, grasping the environmental change caused by socio-environment relationships.

\section{Materials and Methods}

This work started with a series of exercises facilitated by researchers, scholars, and experts who work with policy-science interface and have extensive knowledge about the IPBES framework (Díaz et al. 2015). These exercises took place at the São Paulo School of Advanced Science on Scenarios and Modelling on Biodiversity and Ecosystem Services to Support Human Well-Being from July 1 to 15, 2019.

The main steps to develop positive scenarios included (Figure 1): (i) identifying main drivers (direct and indirect) of forest cover change; (ii) building a conceptual model that links drivers to forest cover change and their interrelationships; (iii) assessing NCPs by considering their local supply and demand; (iv) analyzing the NFF; (v) proposing policies to reduce regional forest loss; (vi) discussing implications for positive scenarios.

\section{Methodological steps}

\section{Outcomes}

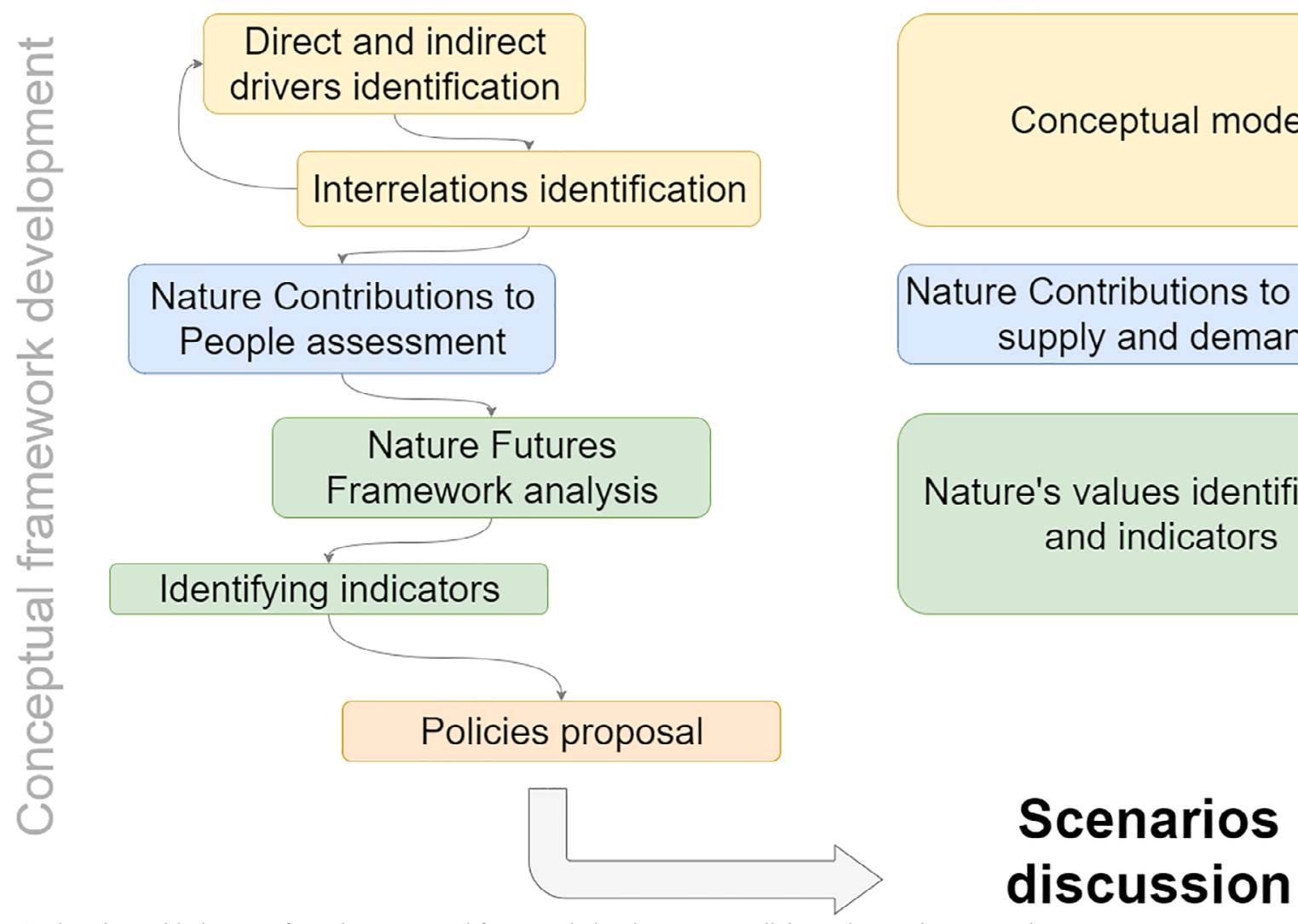

Figure 1. Flowchart with the steps from the conceptual framework development to policies and scenarios proposals. 
Our study object is the forest cover change in Pará state, Brazil (Figure 2). The increased deforestation allied with action of multiples drivers of forest cover change evidence the importance of sustainability policy development in Pará (Figure 2C). The second largest state in Brazil, Pará plays an important role in the socio-economic dynamic in the Brazilian Amazon, sheltering large dams, mining areas and highways projects.

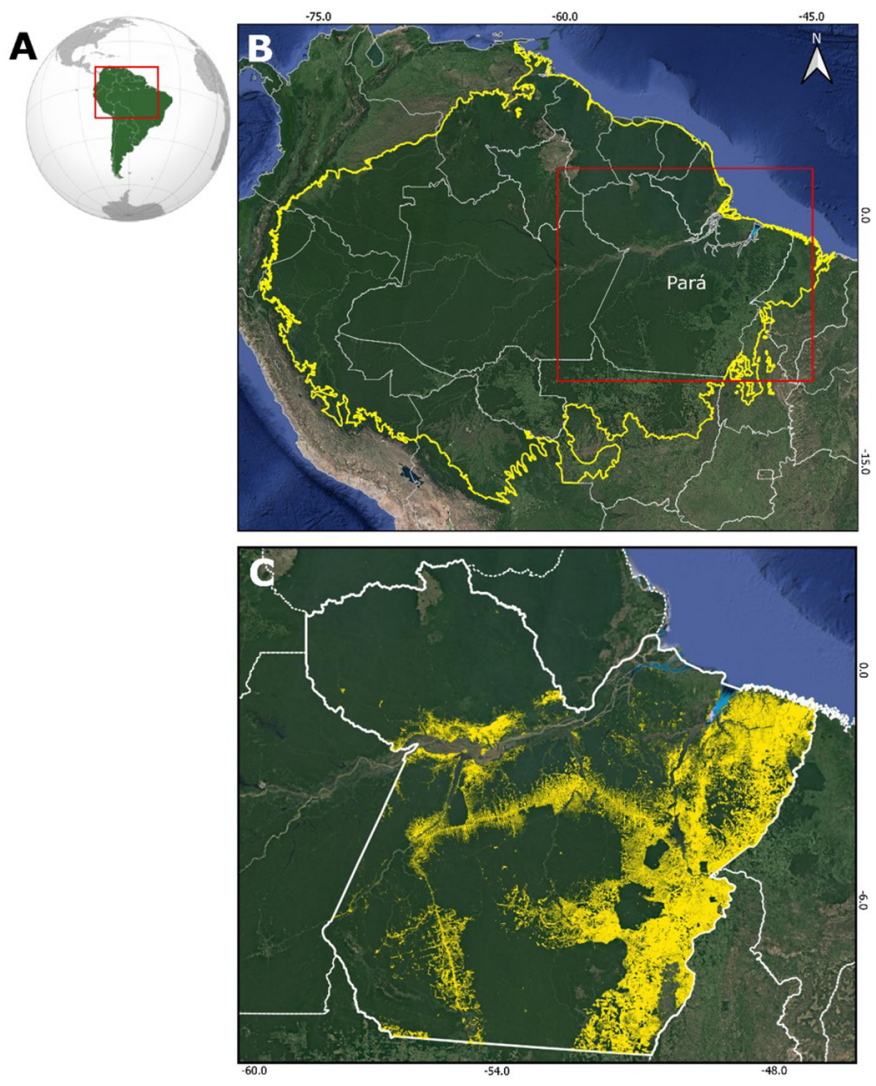

Figure 2. Pará state location. Location of the Amazon basin in South America (A), location of Pará in the Amazon (B), accumulated deforestation in Pará state until 2016 in yellow, eastern portion corresponding to the Brazilian Arc of deforestation within Pará (C).

\section{Identifying the drivers and building the conceptual model}

Forest cover change in Pará state represents our focal component; therefore, our conceptual model grasps this issue by identifying the main drivers, which were used to build policies and envision future scenarios. Direct drivers are those directly affecting forest cover change, while indirect drivers are those altering the level or rate of impact of one or multiple direct drivers (Diaz et al. 2015, Metzger et al. 2017). From drivers' identification, we seek to answer: which are the main anthropogenic activities causing forest loss and decreasing its quality in Pará state during recent years, and how are these activities interconnected? Firstly, we gathered our perceptions regarding the most prominent drivers of forest cover change in Pará, then used a literature review to support our understanding. Using the keywords "deforestation" and "amazon" accompanied by "agriculture", or "mining", or "urban expansion", or "roads", or "climate change", or "logging", or "fires", or "energy demand", or "occupation", we searched in Scopus search on 11 July 2019. Finally, we scoped in works related to Pará state or Eastern Amazon, including those related to indirect drivers, their interplay with multiple drivers and their level of effect on direct drivers.

The drivers and their interconnections were identified through a series of interactions with focus groups and oral presentations, when the most important issues were reviewed before updating the conceptual framework. The exercises were guided by IPBES experts and we used the multiple views of the graduate students who attended the course, but no traditional knowledge or public consultation was taken as reference.

\section{Identifying NCP demand and supply}

Previous studies emphasize the importance of analyzing the dynamics of land-use change and the flow of ecosystem services to inform decision-making (Burkhard et al. 2014). Land-cover refers to the biophysical features of the Earth's land surface (e.g., forest, mangrove, and water). Land-use refers to the use given by humans to exploit available lands (e.g., mining, crops, and pasture) aiming at obtaining specific products or benefits from this use (Turner et al. 1993). Some natural land-covers play important roles in providing different NCPs, while most anthropogenic land-uses represent, by featuring the beneficiaries, the demand. To identify the most critical NCPs, as a requirement to design tailor-made conservation policies, we used a matrix based on Burkhard et al. (2014) to discuss past changes affecting the provision and demand of NCPs (Figure 3 ).

As a reference, we used the land use and cover classes (Figure 3 ) from MapBiomas (MapBiomas Project, 2019). With the classes available, we built a matrix to evaluate the relative importance of each land use and cover providing and supplying NCPs. Based on the knowledge of all authors $(n=7)$, we evaluated the importance of each NCP in the context of Pará state. The average of the grades provided by the group members was calculated to produce one matrix with the importance of each land use and cover types for supplying NCPs and another for demanding NCPs (Figure 3). The supply matrix assessed the capacity of different land use and land cover classes to support NCP's integrity and their provision with the values ranged between 0 (no relevant capacity) and 5 (very high relevant capacity). The demand matrix was also evaluated with values from 0 (no relevant demand) to 5 (very high relevant demand).

Given the importance and consequently, the high score of the regulation of climate NCP, we created the supply/demand budget maps for this NCP (Figure 3). We identified the main processes of land use and cover change using change matrix and transition maps from DINAMICA EGO software (Soares-Filho et al. 2002). The maps used had a spatial resolution of $30 \mathrm{~m}$, and they were downloaded in raster format from https://mapbiomas.org.

\section{Connecting to the Nature Futures Framework - NFF}

NFF is based on a holistic triangular conceptual framework that seeks to maximize the nature benefits for three core human-nature relationships: nature for nature (intrinsic value and function of nature), nature for people (diverse use of nature for interest of people), and nature as culture (human as part of nature) (Rosa et al. 2017, Lundquist et al. 2017). Using this conceptual framework, we seek to identify trajectories leading to positive futures, including not only the protection of ecosystems, but also the conservation of nature's values related to key NCPs. 


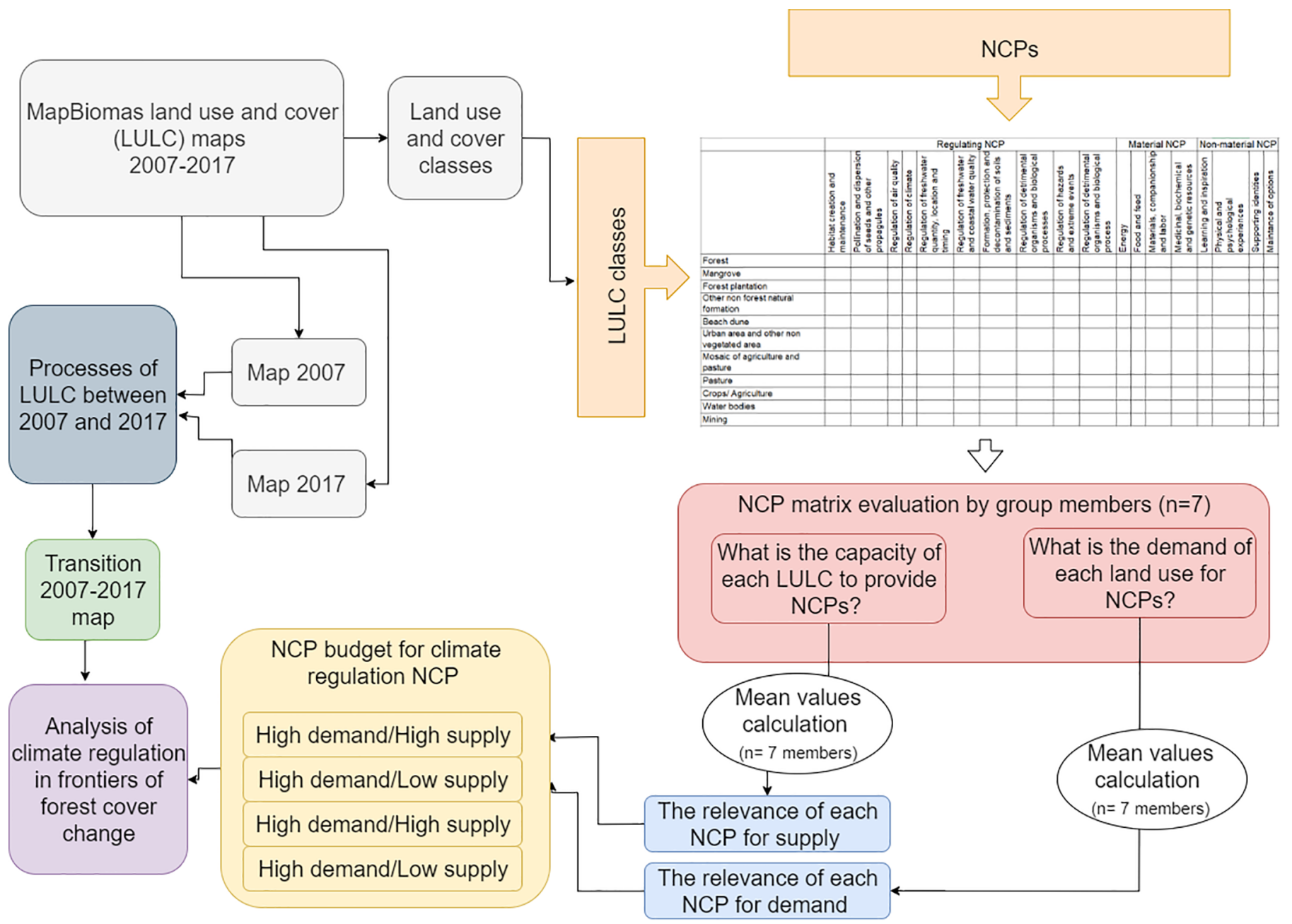

Figure 3. The main steps for NCP matrix calculation and analysis

We started by developing three perspectives on how the main NCPs selected can be valued in Pará state: as nature for nature, as nature for people and nature as culture. Based on the literature, we simulated the integration of different perspectives that several stakeholders may have, including those from indigenous people and local communities. We discussed among the group and with other course participants how values and tradeoffs could be addressed regarding potential futures for Pará state. For example, Freshwater quality and quantity in the Amazon forests could be intrinsically valued as important for nature because it creates habitats for a large range of freshwater biodiversity as well as sustaining the water cycle (Collen et al. 2014). Likewise, this NCP is important for the wellbeing of Amazon people since it supports transportation, fishing and agriculture activities (Junk et al. 2007, Foley et al. 2007). Moreover, this NCP sustains the identity of many local communities whose spiritual practices and knowledge are tied to water bodies (Anderson \& Veilleux 2016). Finally, we proposed indicators to measure and monitor the policy's effectiveness in delivering the nature future envisioned for each NCP. These indicators can be integrated into modeling trajectories and scenarios of nature futures for Pará state (Schoolenberg et al. 2018). For selecting the indicators, we focused on answering three main questions concerning the NCPs and their associated nature perspective (e.g., Regulation of Climate for Nature as Society): what should we measure here? How do we measure this? How feasible is to collect data needed for measuring this? Based on these questions, we included and adapted indicators proposed by IPBES (2018) to evaluate the NCPs. However, there was a need for a broader range of indicators to express the various values and the social and environmental contexts of the Brazilian Amazon region. Thus, as suggested by Schoolenberg et al. (2018), we added indicators based on a literature review and proposed new ones, especially for nature's values related to culture and society.

\section{Proposing policies and discussing potential scenarios}

The policies were designed to tackle the main direct drivers of forest cover change presented in our conceptual model (Lundquist et al. 2017), including mainly targeting consumption behavior and product supply. The policies were firstly built based on the authors' knowledge of the local political context. Then, a literature review was conducted to support and improve the policies, considering public policies previously implemented in the Brazilian Amazon. We intended to propose behavioral change through education for sustainable development, as well as the advance of technology to regulate and monitor land cover changes. We present future positive scenarios that would emerge from the application of our proposed policies, considering societal tendencies, land-use changes, climate changes, and natural resources sustainability. 


\section{Results}

\section{Conceptual model for forest cover change in Pará state}

Based on the literature review and group discussions, we identified eight direct drivers and five indirect drivers (Table 1) leading to forest cover change in Pará state (Figure 4). Forest degradation is defined as a state of anthropogenically induced succession, where ecological processes that underlie forest dynamics are diminished (Ghazoul et al. 2015). Among anthropogenic activities that cause degradation, fire and logging are significantly present in the Amazonian landscape and are extensively studied (Nepstad et al. 1999, Gerwing 2002, Cochrane 2003, Aragão et al. 2007, Silva Junior et al. 2018, Brando et al. 2020). Here, we considered forest degradation caused by fires and logging a direct driver of forest cover change. Land occupation was set as the mean of human occupation with small properties and urban settlements, which differs from agriculture and pasture expansion that represents the advancing of large rural crop production and livestock areas. We do not consider regeneration as one type of forest cover change, focusing only on potential negative drivers.

Table 1. Direct and indirect drivers of deforestation in Pará state and the reference papers supporting drivers impact.

\begin{tabular}{lc}
\hline Direct drivers of deforestation: & References \\
\hline Roads & Soares-Filho et al. (2006); Barber et al. (2014) \\
$\begin{array}{l}\text { Degradation by fire and logging } \\
\text { Hydropower projects }\end{array}$ & Barlow et al. (2012); Anderson et al. (2015); Pinheiro et al. (2016) \\
Urban expansion & Athayde et al. (2019); Chen et al. (2015); Fearnside (2006, 2015) \\
Agriculture and pasture expansion & Tritsch \& Le Tourneau (2016) \\
Land occupation & Cabral et al. (2018); Simon \& Garagorry (2005) \\
Climate change & Brown et al. (2016); Fearsnide (2008) \\
Mining & Anderson et al. (2015); Aragão et al. (2018) \\
Indirect drivers of deforestation: & Sonter et al. (2017); Souza-Filho et al. (2016) \\
\hline $\begin{array}{l}\text { Energy demand } \\
\text { Population growth } \\
\text { Land price }\end{array}$ & Fearnside (2006); Latrubesse et al. (2017) \\
Commodity demand & Perz (2002) \\
\hline
\end{tabular}

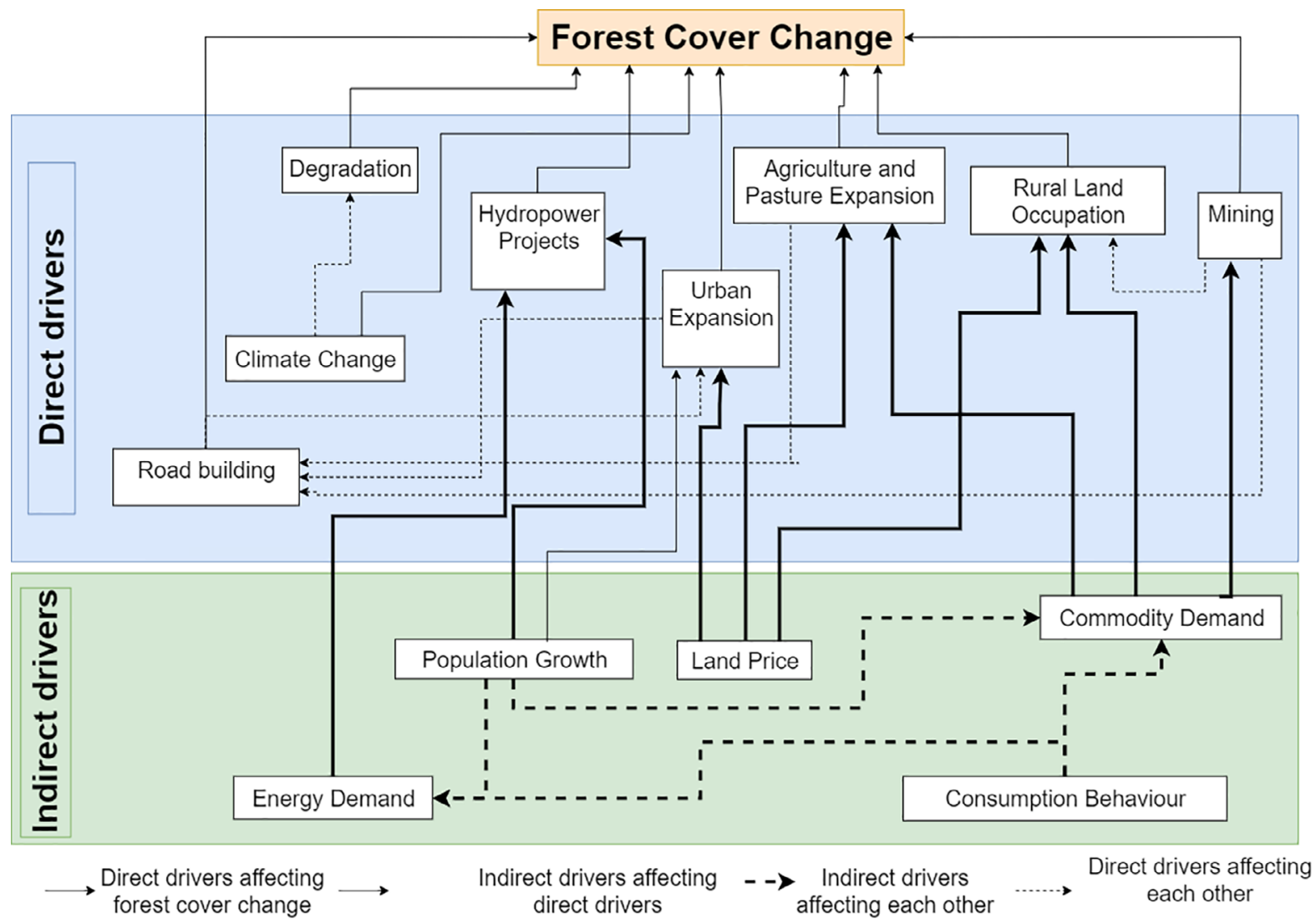

Figure 4. Conceptual framework for assessing deforestation in Pará state, based on IPBES conceptual framework (Diaz et al. 2015). Upper blue zone: direct drivers. Lower green zone: indirect drivers. 
Roads provide access to intact forested areas, resulting in a significant impact on landscape (Soares-Filho et al. 2006). In the Brazilian Amazon nearly 95\% of total deforestation spots are located within $5.5 \mathrm{~km}$ of road networks (Barber et al. 2014). Figure 5A shows an example in the Novo Repartimento municipality, where clearing along roads was caused by land occupation, agriculture expansion and cattle ranching (Tritsch and Le Tourneau, 2016). Besides that, the creation of settlement projects (Yanai et al. 2017) and illegal occupation of undesignated public lands, indigenous lands and conservation units (Fearnside, 2008) influenced deforestation rates in Pará and in other Brazilian Amazon states.

By clearing the remaining forest in the city's outskirts and within the built-up areas, urban expansion plays an important role as a driver of forest cover change in Pará (Tritsch and Le Tourneau, 2016). For example, at Belém metropolitan area, known as "grande Belém", the capital of Pará state, the remaining forest has decreased $64 \%$ due to urban expansion (from $588 \mathrm{~km}^{2}$ to $377 \mathrm{~km}^{2}$ ), between 1986 to 2006 (Leão et al. 2008). In addition, an intense urban growth in Altamira, the largest Brazilian municipality, was triggered by the construction of Belo Monte dam (Figure 5B) (Feng et al., 2017). Although the growth in job opportunities attracts people to these areas, more than 16,000 people have been displaced to urban resettlements as a result of the flooding areas (Feng et al. 2017).

Thus, population growth is an indirect contribution to forest-cover change, as it influences urban expansion and rural land occupation, while triggering infrastructure construction (e.g., dams) and increasing energy and commodities demand. The demand for food also increases with the increasing population, which in turn requires more land for food production (e.g. crops and livestock) (Li et al. 2019). In Pará, two areas faced a significant population growth resulting in intense deforestation during the 1970s and 1980s: Altamira, in the Transamazon Highway corridor; and São Felix do Xingu, in the southeastern frontier of Pará. In Altamira municipality, population growth was caused by colonization projects (settlement project) in the early 1970s, while in São Felix do Xingu migrant farmers and ranchers cleared large areas for pasture (Perz 2002).

Hydropower projects in the Brazilian Amazon produce a great environmental and social impact. Large areas are cleared for the reservoir construction and large indigenous lands and conservation units are flooded, causing displacement and threatening local livelihoods (e.g.

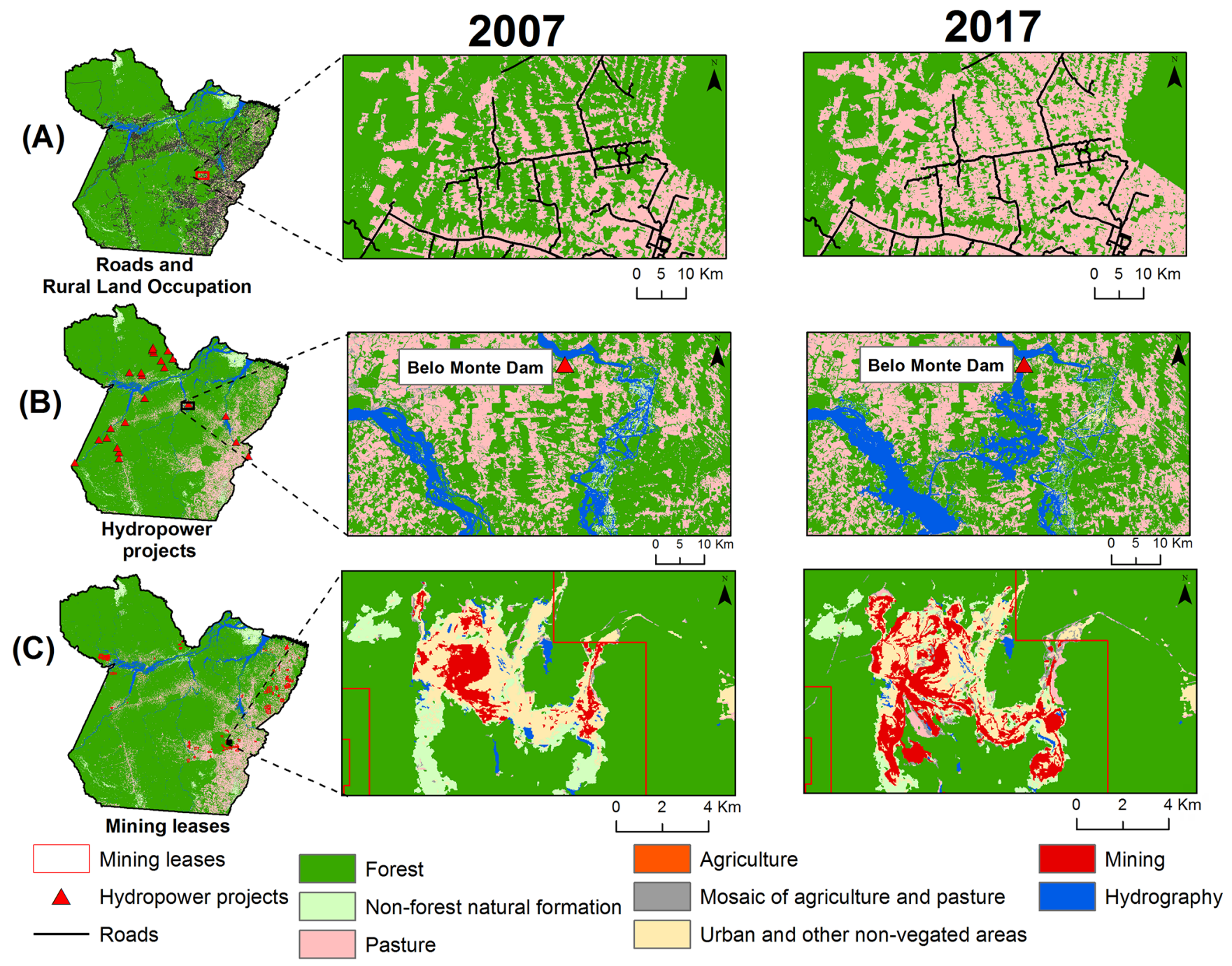

Figure 5. Land cover in 2007 and 2017. (A) Surrounding road building and rural land occupation in Novo Repartimento municipality. (B) Surrounding hydropower projects at the Belo Monte dam. (C) Surrounding mining leases at the Carajás National Forest. 
fisheries and hunting) (Athayde et al. 2019). In addition, reservoirs emit methane, which contributes to climate change (Fearnside 2006, 2015). Figure 5B shows the distribution of dam projects in Pará state, and the zoomed area shows the Belo Monte dam before (2007) and after the flooding (2017). Most of the demand for energy in the Brazilian Amazon comes from the aluminum export industry. In fact, the Brazilian Amazon is home to aluminum smelting companies that are expected to cover most of the international market demand (Fearnside 2006).

Fires make the forest more vulnerable as a way to cause degradation, especially during long periods of dry season (Foley et al. 2007, Silva Junior et al. 2018). Besides that, episodes of severe droughts (e.g. El Niño) tend to become more frequent over the years due to climate change, increasing tree mortality and, consequently, the vulnerability to fires (Nepstad et al. 2007, Brando et al. 2014, Brando et al. 2020). Such processes, as forest degradation and climate change, set up a positive feedback, where degraded forests are increasingly under threat (Rosa et al. 2013). The land price is related to the "improvements" (in Portuguese: benfeitoria) made by the landowner or the state. For instance, benfeitoria considers the presence of pasture or agricultural areas in the farm; the larger the pasture, the higher the land price. In addition, cleared parts of the landholding have the purpose of ensuring land tenure rights, as they show that the land is occupied (Mahar 1989).

Mining activities cause forest cover change within and beyond boundaries of their operation (e.g. infrastructure development, urban expansion, livelihood demands) (Sonter et al., 2017; Siqueira-Gay \& Sánchez 2019). Several mining projects operate in Pará (Lobo et al. 2018) for various metals exploitation (e.g. iron, bauxite, clay, aluminum, tin, limestone, nickel, and silica). Their impact can extend for $70 \mathrm{~km}$ radius from mining leases (Sonter et al. 2017). Figure 5C shows the expansion of iron ore mining activities in Carajás from 2007 to 2017.

Forest cover change drivers in Pará state and their interrelations represent a very complex system. A simplified description of our conceptual model is shown in Figure 4. We chose to maintain the links of major importance only, in order to keep a simplified feasible version of our conceptual framework. However, the model considers that policyrelevant factors, such as commodity price, access to credits for cattle ranching, Forest Code enforcement level, and shifts in policy paradigms caused by changes in the government will also affect the dynamics of forest cover change (Rodrigues-Filho et al. 2015).

\section{Forest cover change influences on key NCPs}

In the ten years' period under analysis (i.e. 2007 to 2017), forest cover in Pará state showed a reduction of $1.6 \%$, representing a mean loss of $1,592 \mathrm{~km}^{2}$ per year. In the same time, agriculture and pasture indicated an increased by $7.9 \%$. From the total forest area cleared $\left(15,921 \mathrm{~km}^{2}\right)$ during this period, $82.7 \%\left(13,170 \mathrm{~km}^{2}\right)$ was converted into pasture and agriculture. Forest plantations and mining were the classes with the highest percentage of increase in ten years, with $922.8 \%$ (166.7 $\mathrm{km}^{2}$ ) increase for forest plantation and $168.8 \%\left(71.7 \mathrm{~km}^{2}\right)$ for mining activities. Urban and other non-vegetated areas also had an important increment; this class showed an increase of $41.8 \%\left(710.0 \mathrm{~km}^{2}\right)$ and could be associated with urban expansion in the Pará state.

We evaluated the NCP supply and demand of each land use and land cover considering the Pará state study area. The three NCPs with higher supply capacity are materials and assistance, energy, food \& feed (Table 2). Forest and mangroves areas are the most important land- cover classes for providing NCPs (Figure 6). The NCP demand analysis revealed the regulation of freshwater quantity, regulation of climate and formation, protection, and decontamination of soils and sediments as the most relevant (Table 3). The urban areas and mosaic of agriculture and pasture represent the land-uses with the highest NCPs demand.

We also evaluated the balance between supply and demand (i.e., budget of NCP) of the regulation of climate NCP (Figure 7). Thus, natural formations and hydrography are areas with high supply and low/intermediate demand of NCP. Agriculture, pasture and urban areas had high demand and low supply. Forest and mangroves present low demand and high supply. The frontiers of forest cover changes, such as roads, are regions of special attention for conservation due to the high demand and supply of natural resources. Rivers and pasture have an intermediate level of importance in providing and demanding NCPs, while beach dunes have the lowest levels of supply as well as demand.

\section{Connecting to the Nature Futures Framework}

Each key NCPs can be valued differently according to perspectives on how people relate to nature. For example, we found that food $\&$ feed, energy, and materials and assistance can be more related to values of "nature for people" and "nature as culture" than to "nature as nature". This is because these NCPs are focused on human wellbeing and, specifically, on the elements from nature that directly sustain people's physical existence and material assets (known as "Material NCPs", Díaz et al. 2018). By contrast, freshwater regulation, climate regulation, and soil protection can be highly valued according to all perspectives because these "Regulating NCPs" are key for sustaining functional and structural aspects of organisms and ecosystems and, indirectly, the quality of human life (Díaz et al. 2018). We also identified a set of indicators for each NCP and different values (Table 4) to reflect the plurality of human-nature relationships. For the NCP of regulation of water quality and quantity we presented cultural, such as maintenance of water bodies important for cultural practices and recreation, socioeconomic, such as navigability index, as well as other usual indicators such as parameters for aquatic habitat quality.

\section{Policies proposal}

The first legal environmental regulation device was the Forest Code of 1934 (replaced in 1965), updated in 2012 as the "New Forest Code" (Soares-Filho et al. 2014), which establishes usage limits and protection of native vegetation within private properties. In 2004, the federal government implemented the Action Plan to Prevention and Control of Deforestation in the Legal Amazon (PPCDAm), aiming to gradually and continuously reduce deforestation in the Legal Amazon, as well as to provide subsidies to a more sustainable regional development (Maia et al. 2011). The plan considered a chain of deforestation causes to organize its four thematic axes, which are i) Land and territorial planning, ii) Environmental monitoring and control, iii) Promotion of sustainable production activities, and iv) Economic and regulatory instruments, and each axis was integrated during a phase of the plan. The PPCDAm, which is now in its fourth phase, contributed to the reduction of deforestation in the region through reinforcement of monitoring and surveillance actions and by expanding the conservation unit's system (Arima et al. 2014, Ministério do Meio Ambiente 2016). Also, some international instruments, such as the Amazon Fund and 
Table 2. Assessment of the NCP supply matrix of different land-use and land-cover classes. Color gradient indicates supply values. High values of supply tend to be red, low values tend to be green. Adapted from Burkhard et al. (2014).

\begin{tabular}{|c|c|c|c|c|c|c|c|c|c|c|c|c|c|c|c|c|c|c|}
\hline $\begin{array}{l}\text { Other non-forest natural formation } \\
\text { (e.g., savanna, campinarana, grassland) }\end{array}$ & 4 & 4 & 4 & 4 & 4 & 3 & 4 & 4 & 4 & 4 & 3 & 4 & 3 & 4 & 4 & 4 & 4 & 4 \\
\hline Beach dune & 3 & 1 & 1 & 1 & 2 & 2 & 3 & 2 & 2 & 2 & 2 & 0 & 2 & 2 & 4 & 4 & 3 & 3 \\
\hline $\begin{array}{l}\text { Urban area and other non-vegetated } \\
\text { area (e.g., roads, constructions) }\end{array}$ & 0 & 0 & 0 & 0 & 0 & 0 & 0 & 0 & 0 & 0 & 1 & 0 & 2 & 0 & 2 & 2 & 1 & 1 \\
\hline $\begin{array}{l}\text { Mosaic of agriculture and pasture (area } \\
\text { where pasture and agriculture could not } \\
\text { be separated in different classes }\end{array}$ & 1 & 2 & 1 & 1 & 1 & 1 & 1 & 1 & 1 & 1 & 2 & 4 & 2 & 1 & 2 & 1 & 1 & 1 \\
\hline Pasture & 0 & 1 & 1 & 1 & 0 & 0 & 0 & 0 & 1 & 1 & 1 & 3 & 2 & 1 & 1 & 1 & 1 & 2 \\
\hline Crops/ Agriculture & 2 & 2 & 1 & 1 & 1 & 0 & 1 & 1 & 1 & 1 & 3 & 4 & 2 & 2 & 2 & 1 & 1 & 1 \\
\hline
\end{tabular}

the Reducing Emissions from Deforestation and Forest Degradation (REDD) program were created to support activities and policies to reduce deforestation at local scale (Correa et al. 2019; Pinsky et al. 2019). In accordance to national initiatives, Pará state has created the Green County program, to tackle forest loss in the municipalities with higher deforestation rates and implemented the Rural Environmental Registry (Cadastro Ambiental Rural - CAR) which forced landowners to submit their land boundaries, therefore supporting the monitoring of legal reserves (Nepstad et al. 2014). Another environmental program in action in Pará is the Ecological ICMS, which refers to an ecological fiscal transfer, from the state to municipalities committed to environmental actions. However, the application of this program remains controversial (Tupiassu et al. 2019).

The policies we propose represent a response to address the drivers of forest cover change, their interconnections (Figure 4), and the NCP demand analysis (Section 2 of results). The policies intend to reduce forest cover change mainly by tackling two key drivers: consumption behavior and product supply.

\section{Pará minus: Land management to tackle illegal deforestation}

This policy intends to reduce mainly the illegal deforestation in Pará state, one important pathway of forest cover change. By proposing this policy, we aim to address the drivers of rural land occupation, agriculture and pasture expansion, unofficial road building and forest degradation. A similar action plan has been applied in Pará by the Federal Prosecutors' Office (Ministério Público, MPF-PA) during the second phase of the Action Plan to Prevention and Control of Deforestation in the Legal Amazon (PPCDAm-II, 2008-2011), resulting in a reduction of deforestation in the state. The actions focused on regulating the complete supply chain, including the production, distribution and the buyers' responsibility as well as regulation of legal reserves inside agricultural properties. With the implementation of these actions, supermarkets started to require an origin label for the meat they purchase (Arima et al. 2014).

Pará minus draws on the notions of co-management and decentralized environmental governance, where the knowledge of direct resource users is prioritized to build adaptive forest governance (Ostrom, 2015). Here, users coordinate actions to manage in a sustainable way, guaranteeing access and control, to natural resources (Ribot \& Peluso 2009).

This policy proposes the decentralization of governance systems by conceding power to local communities to manage their forest with the assistance of multiple institutions (e.g., NGOs) and implement monitoring efforts to avoid new areas of illegal deforestation. The core 

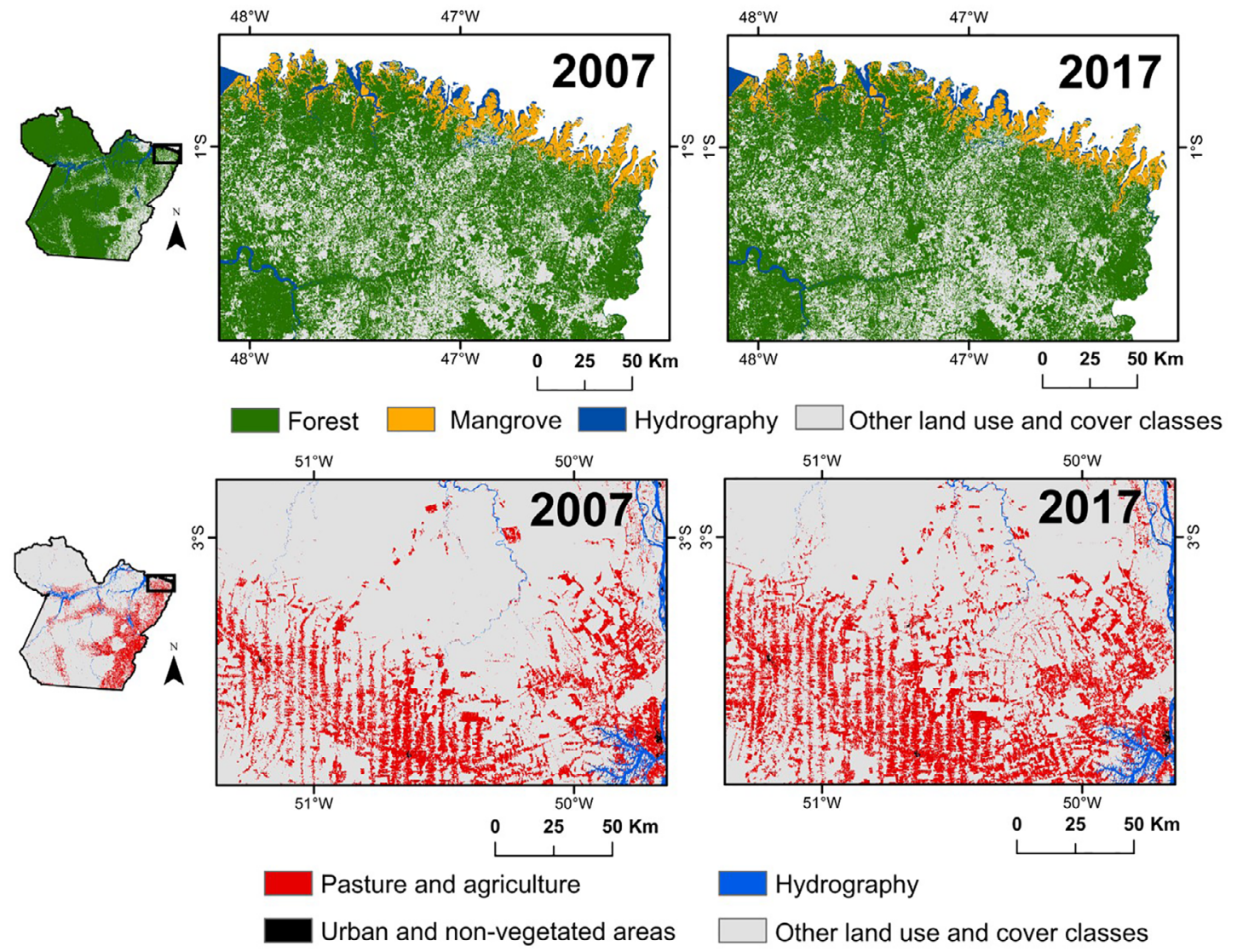

Figure 6. Land cover in 2007 and 2017 showing the relevant areas of NCPs supply in Pará state.

actions to be performed as part of this policy include: i) Enforce forest decentralization efforts to allow small governance units taking decisions about their resources in a sustainable way; ii) Provide technological tools and training to communities to facilitate sustainable development and monitoring efforts; iii) Enforce the protection of indigenous territories and protected areas, by creating an inheritance tax scheme and fines to illegally cleared forest areas; iv) Perform a land reform to distribute underused or abandoned land to individuals or organizations committed to sustainability and conservation efforts or return the land to indigenous or traditional communities; v) Regulate for the mandatory sustainable use of undesignated public lands, and prohibit (with fines applicable) clearing of pristine forest areas; vi) Create alliances and strengthen existing ones to make the forest monitoring and controlling efforts more effective, while facilitating social learning process in the local communities. Social learning is a key element to ensure participatory and adaptive resource governance. It is defined as "collective action and reflection that occurs among different individuals and groups as they work to improve the management of human and environmental interrelations" (Keen et al. 2012).

\section{Pará Consumo: Change consumption behavior}

In Portuguese, Pará Consumo is a pun with the name of the state, which means "stop". This way, the name of the policy means to stop consuming. Consumption behavior is a key indirect driver of forest loss and climate change (Figure 4). For instance, excessive meat consumption and soy plantation to produce animal food are relevant contributors to agriculture and pasture expansion. Thus, we suggest that environmental education can change the current population consumption behavior and thus, reduce the demand for meat and, consequently, the pressure for clearing new areas to agriculture and pasture. Although few investigations were found about the effectiveness of policies to tackled consumption behavior in the Amazon, Assunção et al. (2015) demonstrated that the lower the price of agricultural outputs, the lower are the deforestation rates. Therefore, a behavioral change towards consumption reduction will also produce deforestation decreases.

The following actions would be undertaken under this policy: i) Create an educational program to promote awareness on NCP provision, the value of forest conservation and damage caused by cattle ranching. This program would be within the whole educational system by restructuring the curriculum; ii) Promote other options for protein consumption instead of beef; iii) Create a tax incentive for large companies that join the beef moratorium (an agreement of not buying meat from newly deforested areas) or that support the educational program of awareness on NCP provision (action i).

\section{Positive scenarios}

We propose positive scenarios for Pará state, considering the trends of the main drivers of forest cover change identified and the suggested policies (Figure 8). We envision three future scenarios following the two proposed policies. The first scenario considers that only Pará minus was properly implemented, the second scenario considers that only Pará consumo was properly implemented, and the third scenario involves the trends in drivers following the proper implementation of both policies in Pará state. 
Table 3. Assessment of the NCP demand matrix. Color gradient indicates demand values. High values of demand tend to be red, low values tend to be green. Adapted from Burkhard et al. (2014).

\begin{tabular}{|c|c|c|c|c|c|c|c|c|c|c|c|c|c|c|c|c|c|}
\hline & 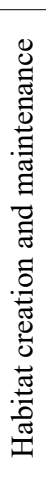 & 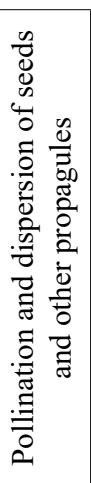 & 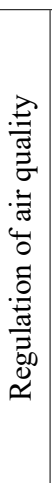 & 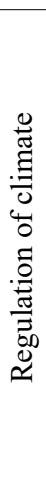 & 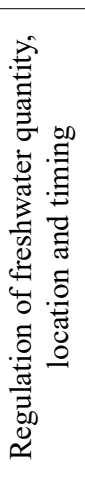 & 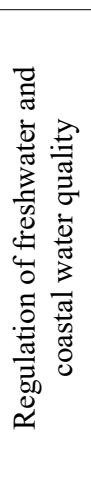 & 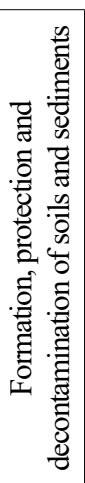 & 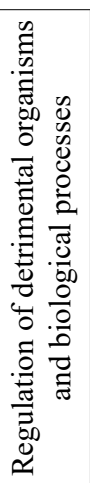 & 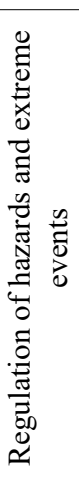 & 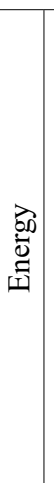 & 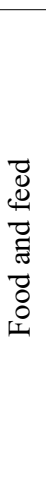 & 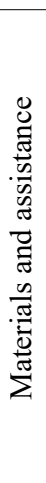 & 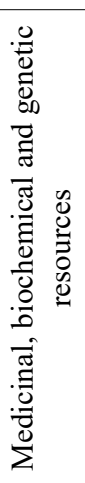 & 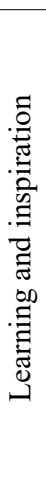 & 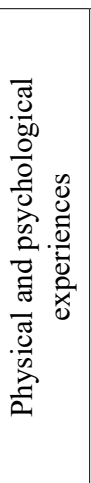 & 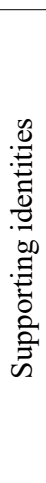 & 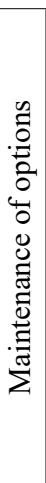 \\
\hline Forest & 2 & 2 & 1 & 1 & 2 & 1 & 0 & 2 & 1 & 1 & 1 & 1 & 1 & 0 & 1 & 1 & 1 \\
\hline Mangrove & 1 & 1 & 1 & 1 & 1 & 1 & 1 & 1 & 1 & 0 & 1 & 1 & 1 & 1 & 1 & 1 & 0 \\
\hline Beach dune & 1 & 0 & 0 & 0 & 0 & 0 & 0 & 0 & 0 & 0 & 0 & 0 & 0 & 0 & 0 & 0 & 0 \\
\hline $\begin{array}{l}\text { Urban area and other non vegetated } \\
\text { area (e.g., roads, constructions) }\end{array}$ & 2 & 2 & 4 & 4 & 4 & 4 & 3 & 3 & 4 & 4 & 4 & 4 & 3 & 4 & 4 & 3 & 4 \\
\hline $\begin{array}{l}\text { Mosaic of agriculture and pasture (area } \\
\text { whre pasture and agriculture could not } \\
\text { be separeted in different classes }\end{array}$ & 2 & 4 & 2 & 4 & 4 & 3 & 4 & 3 & 3 & 3 & 2 & 3 & 2 & 1 & 1 & 1 & 1 \\
\hline Pasture & 2 & 2 & 2 & 4 & 4 & 3 & 3 & 3 & 3 & 2 & 2 & 3 & 2 & 1 & 1 & 1 & 1 \\
\hline Crops/ Agriculture & 2 & 4 & 2 & 4 & 4 & 2 & 4 & 4 & 4 & 2 & 2 & 2 & 2 & 1 & 1 & 1 & 1 \\
\hline Water bodies & 1 & 0 & 0 & 2 & 2 & 2 & 1 & 1 & 0 & 1 & 1 & 1 & 1 & 1 & 1 & 1 & 1 \\
\hline Mining & 2 & 1 & 2 & 1 & 2 & 2 & 3 & 2 & 2 & 5 & 1 & 3 & 1 & 1 & 1 & 1 & 1 \\
\hline
\end{tabular}

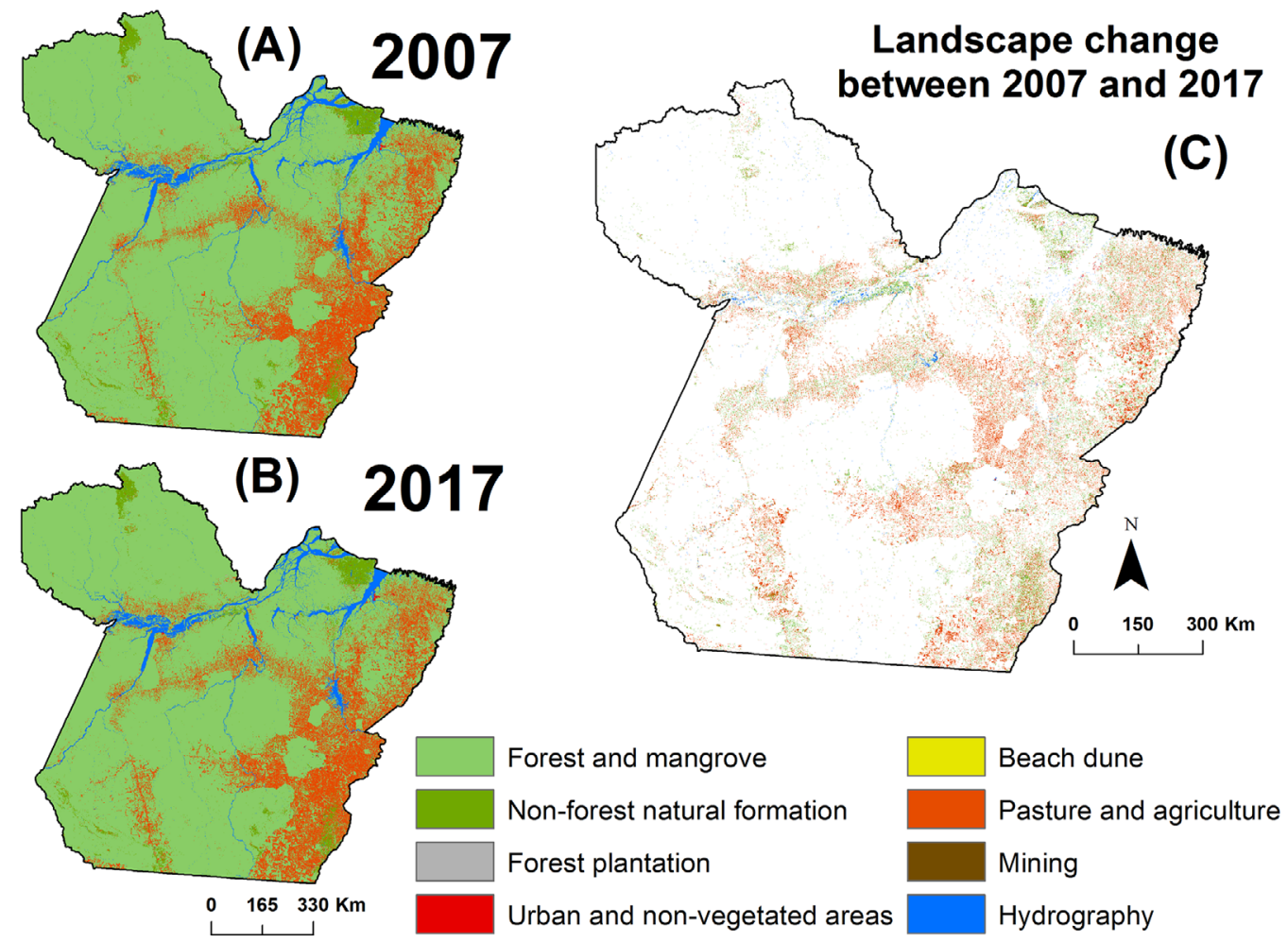

Figure 7. Balance for budget of supply and demand for the regulation of climate in (A) 2007 and (B) 2017 and (C) the change between 2007 and 2007 in the Pará state. 
Siqueira-Gay J. et al.

Table 4. Valuation of key NCPs for Pará state into Nature's values, their related variables and proposed indicators for monitoring.

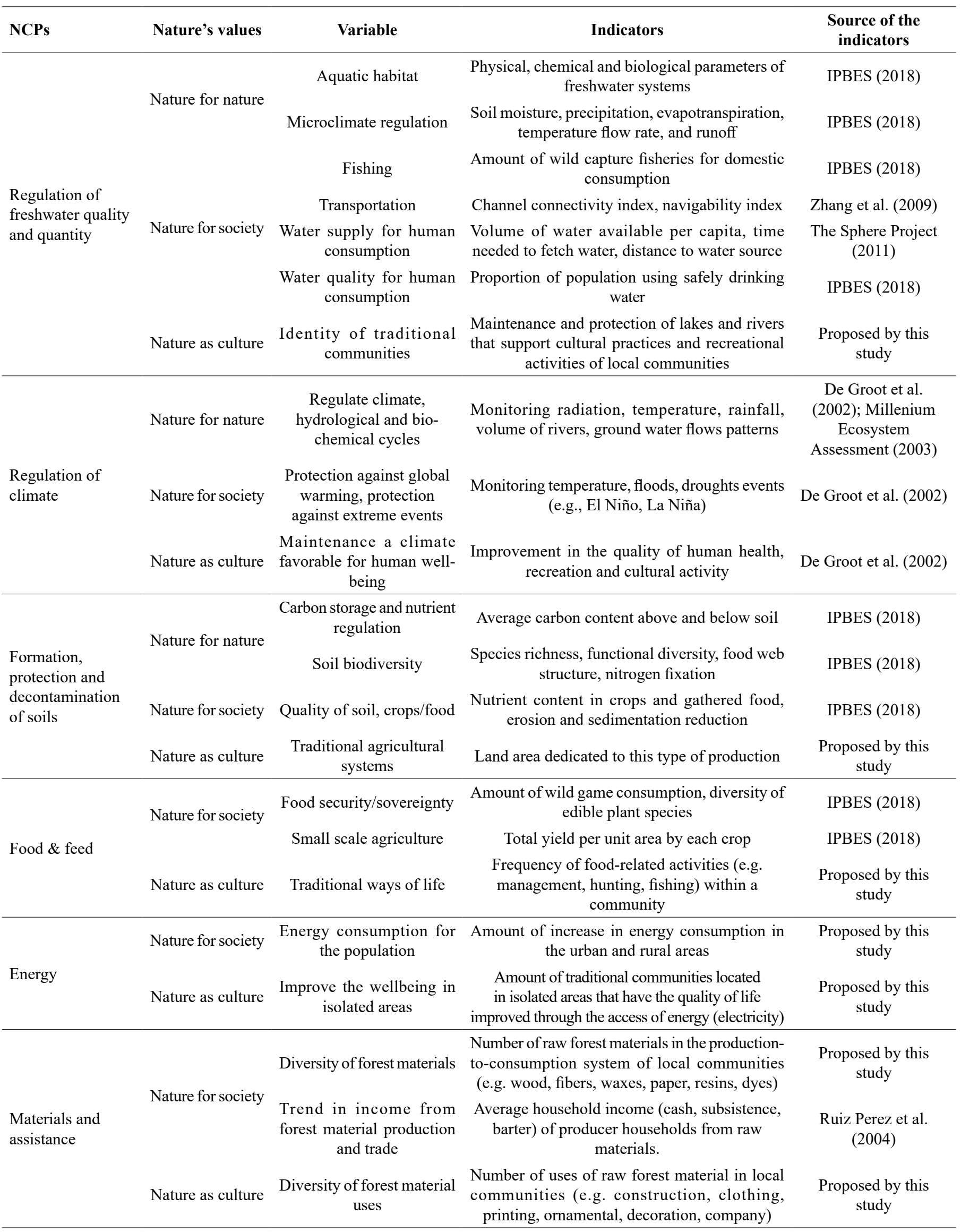




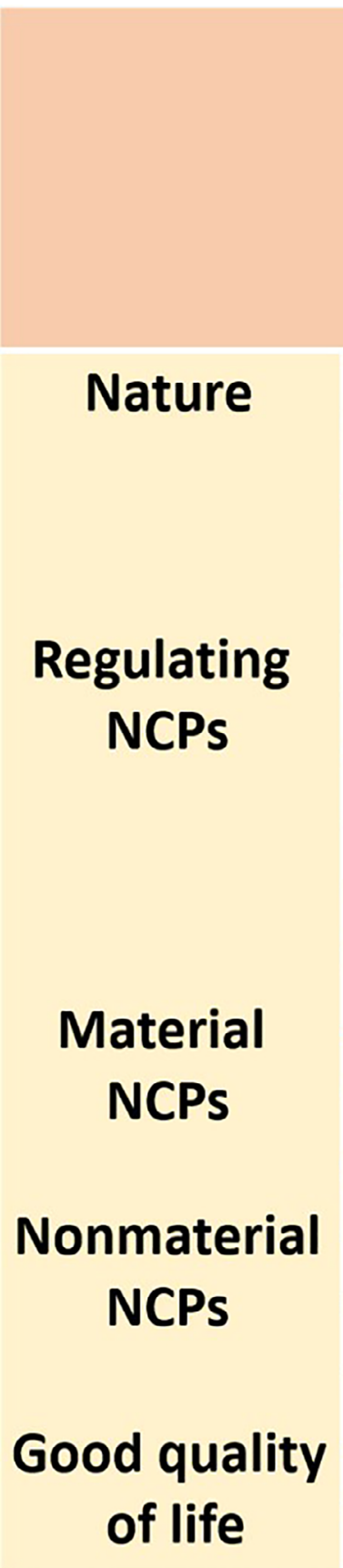

Biodiversity, ecosystems and processes

Pollination
Regulation of air quality
Regulation of climate

Regulation freshwater quantity
Regulation of freshwater quality

Formation of soils

Regulation of hazards

Regulation of human detrimental organisms

Food and feed
Materials (forest products)
Water resources

Learning and inspiration

Physical and psychological experiences

Supporting identities

Education and knowledge

Physical, mental, and emotional health

Security and livelihoods
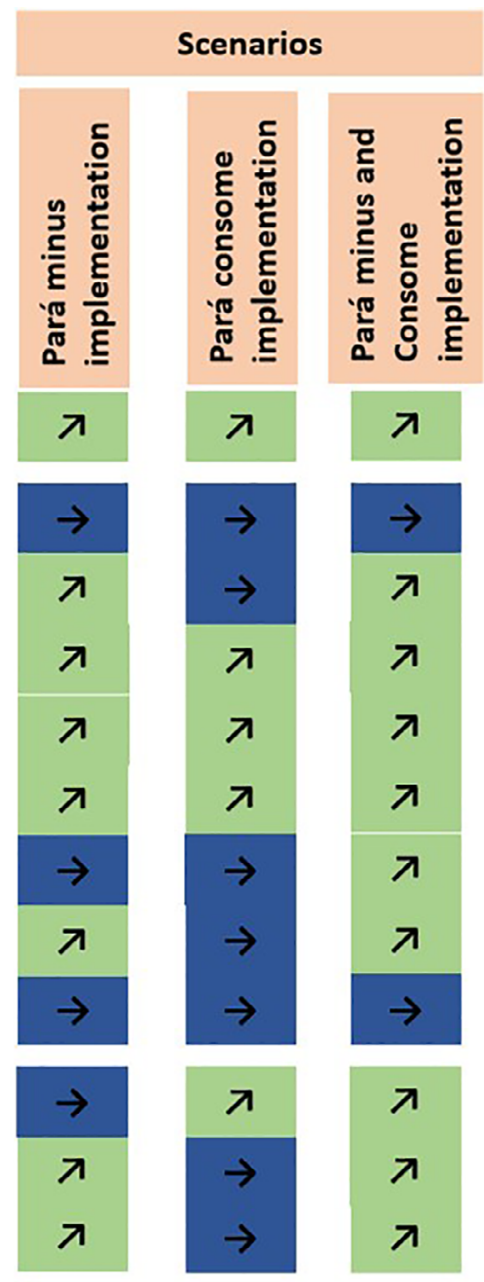

フ

フ

ᄀ
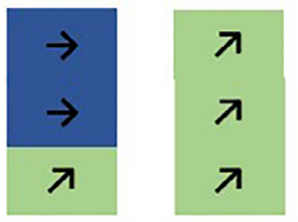

フ

入

フ

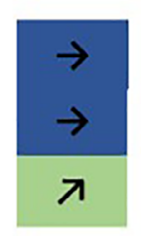

$\lambda$
$\pi$

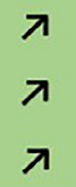

\section{$\pi$ Increase $\rightarrow$ Stable}

Figure 8. Envisioned impacts on nature, Nature Contributions to People and good quality of life according to the three proposed future positive scenarios for Pará state.

Scenario 1 - positive outcomes from the application of Pará minus

We have the maintenance of the forest cover area in Pará state through regional development and sustainability, conservation and sustainable development actions. Decentralization actions would focus on local development and welfare, controlling and preventing the occurrence of new deforestation through degradation, road building, mining, land occupation, agriculture, and pasture expansion.
Technological input would change the "business as usual" in the region, reducing deforestation and ensuring local production.

A land reform and the regulation of undesignated public lands would also strengthen conservation value through sustainable use, production, and a conservation budget from local government. Social learning development is a fundamental tool for ensuring participatory and adaptive resource governance; in the long term, it would work to ensure that conservation and development (through sustainability) can work together in the same stage by promoting the interaction 
of stakeholders to reflect on the problems they face and integrate their knowledge (Schmidt 2017, Pahl-Wostl et al. 2007). Economic development would be based on the non-extractives' use of deforested areas (e.g. eco-tourism and payment for ecosystem services projects), which would prevent deforestation. Traditional extractive activities from the region (e.g. açaí and Brazil nuts extraction) would adopt sustainable practices and respect product seasonality, integrating the traditional way of extraction with technology and sustainability. Thus, the enacted laws might ensure land-use change control, regulating climate change and the sustainable use of natural resources.

\section{Scenario 2 - positive outcomes from the application of Pará Consumo}

The positive outcomes of this scenario include: conservation and sustainability through education to shift consumption behavior; an enhanced awareness of the value of the NCPs and the damage caused by cattle ranching; an increment in social welfare by promoting life quality supported by NCPs (nature and society development) and economic development (e.g. jobs, local income flow). This scenario envisions changes in other types of social behavior through the application of innovative strategies for fostering sustainability. Among these strategies is the creation of a food market that motivates the production and consumption of local products. This would not only have positive gains in fighting climate change due to the reduction of carbon emissions from transportation, but it may create nature recreational opportunities for people. In large urban centers, this would also promote the establishment of urban farms, committed to low emissions and sustainable production. Besides that, the institutions would gain legitimacy to stop land-use change and replace it through sustainable use (through tax incentive), which in turn would tackle climate change and environmental sustainability by creating a new economy that does not depend on extractive industries while ensuring the provision of natural resources for future generations. Aligned with the shift in consumption behavior and the increased awareness of NCPs value, there would emerge an increased awareness to waste destination and recycling.

\section{Scenario 3 - Positive outcomes from the application of both policies}

This scenario envisions regional sustainable development together with environmental awareness and behavioral change. This scenario considers the outcomes from successfully applying policies one and two: forest management decentralization, technology for sustainability, reinforcement of protected areas, a substantial reduction in deforestation rate, conservation and sustainable use of undesignated public lands, and an educational behavioral change towards sustainable consumption. Other positive outcomes include sustainable economic development, based on green solutions, controlling or reducing drivers of forest cover change; increased social development; employment generation based on NCPs provision and maintenance; cultural empowerment through social learning; land-use and climate change control through sustainable use of natural resources.

\section{Discussion}

The IPBES framework allowed us to discuss the main drivers and their implications considering diverse socio-cultural aspects and biodiversity conservation and human well-being. We argue that the proposed policies would support positive scenarios by addressing the main drivers and promoting positive changes in the region.

Roughly $65 \%$ of Brazilian timber extraction takes place in Pará state (Verissimo 1998, Pinheiro et al. 2016). The construction of roads (1970s) has provided access to previously remote forest areas, connecting the Brazilian Amazon to central and northeast Brazil. This new connection has contributed to the migration in the region, fostering access to natural resources and facilitating trading of forest resources, while producing economic development in the region. Also, these policies led to a regional transformation of smallholder subsistence farming into extensive large-scale farming (Müller-Hansen et al. 2019).

Unlike the Brazilian Cerrado, fires are not part of the natural cycles in the Amazon. Instead, a close link between fires and anthropogenic material actions s (e.g., deforestation and climate change) and development models that intensify resource extraction and violation of indigenous rights can be outlined for the Amazon region (Aragão et al. 2018), considerably increasing carbon emissions and reducing NCP supplies (Anderson et al. 2015). Although hydropower projects are defended as clean and renewable energy source, studies have shown the high impact of damming Amazon rivers to local biodiversity (aquatic and terrestrial) (Latrubesse et al. 2017) and human livelihoods, including local traditional and indigenous people (e.g. loss of local food sources and population displacement) (Athayde et al., 2019; Fearnside 2015).

Given this background, this study proposes a positive vision (i.e. "what we want?") for the Amazon forest in Pará state, and the policies and scenarios ("how to get there?") to support this vision. The IPBES and Nature Futures Framework (Lundquist et al. 2017, Díaz et al. 2018) encouraged us to develop a more holistic future for the Amazon forest in Pará, where not only intrinsic values of forests for biodiversity are considered but also their values for human wellbeing and cultural maintenance. We also proposed a set of indicators to track how we approximate these positive visions. We note that some indicators would have compatible desired trajectories. Taking water as an example, Funder the nature for nature perspective, we envision a future where Amazonian freshwater bodies provide a healthy aquatic habitat according to physical, chemical and biological parameters. This trend would be compatible with improving the provision of drinking water to the local population, an indicator for nature for people. Besides that, there are trade-offs between the trends of some indicators and different nature's perspectives. Fishing by local communities and the maintenance of their traditional ways of life are indicators for nature for people and nature as culture, respectively (Table 4). But if not sustainable, the increases of fishing to an industrial level could modify the natural ecological communities of freshwater systems, negatively affecting aquatic habitat and, therefore, the nature as nature indicators.

It is instrumental to understand how the indicators are connected to integrate them into the models and future scenarios, as well as provide and historical and consistent data time series. The latter represents a challenge for the new proposed indicators, especially those related to "nature as culture" value, such as an in-depth anthropological assessment of traditional knowledge and food-related practices in local communities. Likewise, it is necessary to work with local traditional and indigenous communities for obtaining the required data using both qualitative and quantitative methods. 
The policies focused on the drivers of land management and consumption behavior, revealing the reflection on interventions that can be explored to produce positive futures for the region. We emphasize that policies that former governments have implemented, including the PPCDAm (Herrera et al. 2019, Gibbs et al. 2015) should be strengthened instead of weakened as indicated trend of Brazilian government.

Given the importance of creating scenarios based on biodiversity conservation and human wellbeing (Rosa et al. 2017), we extrapolate the implications of the successful implementation of our proposed policies. A way to create hurdles for illegal deforestation could be by fomenting land control in protected areas and regulating the use of undesignated public lands, allied to empower local communities. Moreover, we evidence the importance of consumption behavioral change in order to address the decreasing demand for unsustainable commodities and, consequently, avoiding forest cover change. Therefore, we emphasize the prominent role played by education as the most important way to address consumption behavior by creating awareness of interrelations between people's everyday choices of transportation, food and clothing, for example, with climate change. The educational curricula should be revisited having a pluricultural worldview, similar to what Ecuador and Bolivia have intended through their Constitutions under the notions of Sumak Kawsay and Sumak Qamaña, respectively (Acosta, 2010). Such a worldview represents an avenue to legitimize indigenous knowledge and practices. For example, to raise awareness within the young generations, the curricula can include reading indigenous stories that show the close link between indigenous people and nature, which can ultimately influence societal behavior.

\section{Conclusions}

There is a lack of integrative view on how forest cover change affects the ecosystem and human wellbeing. In order to provide a broader picture of environmental change, we firstly identified drivers of deforestation and potential links between them to illustrate how they are affecting forest cover change in Pará state. We identified as direct drivers: (i) roads construction; (ii) forest degradation; (iii) hydropower projects; (iv) urban expansion; (v) agriculture and pasture expansion; (vi) rural land occupation; and (vii) mining; (viii) climate change; and as indirect drivers: (i) energy demand; (ii) population growth; (iii) land prices; (iv) commodity demand; (v) consumption behavior. In Pará state, regulation of freshwater quantity, regulation of climate and formation, protection, and decontamination of soils and sediments are the most relevant NCP for demand and the materials and assistance, food \& feed and energy are critical for supply. Considering the NCP climate regulation, the frontiers of deforestation (e.g. roads) are regions of special attention due to the high demand and supply of natural resources. Rivers and pasture play an intermediate role providing and demanding NCPs, while beach dunes present the lowest level of supply as well as demand.

Our proposed policies aimed at addressing the main drivers and discuss positive scenarios to conserve material and immaterial aspects of the pluralist environment of Pará state. We found that it is essential to expand the data available on indicators to track possible changes in the values of each NCPs, especially for those values related to societies and cultures. It is necessary to move beyond existing metrics for depicting an aspirational future for the Amazonian forest and the sustainability of NCPs in Pará state.
Although we advanced in terms of understanding current drivers of change and how they are interconnected, our conceptual model certainly has some limitations. Our results did not capture the entire socio-ecological reality behind forest cover change in Pará since our conceptual model did not include the knowledge of local forest users and indigenous people. It could be refined by adding the knowledge of other stakeholders (e.g., indigenous people, local population and governments) because we have not been able to include fundamental knowledge coming from resource users.

\section{Acknowledgments}

We thank the São Paulo Research Foundation (FAPESP) for financial support of the São Paulo School of Advanced Sciences on Scenarios and Modelling on Biodiversity and Ecosystem Services to Support Human Well-Being. We are grateful for the support of all professors and colleagues that attended the course. We thank to one anonymous reviewer for the important contribution to the final version of this work. Very special thanks to Charlotte Smith for her intellectual contribution and technical support during the workshop. This study was financed in part by the Coordenação de Aperfeiçoamento de Pessoal de Nível Superior - Brasil (CAPES - Finance Code 001). RCB received a travel grant from Instituto Tecnológico Vale. RCB and ACMP thank to CNPq for financial support (processes numbers 381296/2018-0 and 140877/2018-5 respectively).

\section{Author contributions}

Juliana Siqueira-Gay: substantial contribution in the concept and design of the study, to data collection and to data analysis and interpretation; wrote, added intellectual content and review the final version of the manuscript; provided significant contribution to manuscript preparation

Aurora Miho Yanai: substantial contribution in the concept and design of the study, to data collection and to data analysis and interpretation; wrote, added intellectual content and review the final version of the manuscript.

Janeth Lessmann: substantial contribution in the concept and design of the study, to data collection and to data analysis and interpretation; wrote, added intellectual content and review the final version of the manuscript.

Ana Carolina M. Pessôa: substantial contribution in the concept and design of the study, to data collection and to data analysis and interpretation; wrote, added intellectual content and review the final version of the manuscript.

Danilo Borja: substantial contribution in the concept and design of the study, to data collection and to data analysis and interpretation; wrote, added intellectual content and review the final version of the manuscript.

Moara Canova: substantial contribution in the concept and design of the study, to data collection and to data analysis and interpretation; wrote, added intellectual content and review the final version of the manuscript.

Rafael Borges: substantial contribution in the concept and design of the study, to data collection and to data analysis and interpretation; 
wrote, added intellectual content and review the final version of the manuscript.

\section{Conflicts of interest}

All authors declare that to have no conflict of interest related to the publication of this manuscript.

\section{Ethics}

All authors declare to be in compliance with all ethical stablished guidelines. No human subject was used in this study.

\section{Data availability}

All data used for the development of this study is already made available in methods section.

\section{References}

ACOSTA, A. 2010. El Buen Vivir en el camino del post-desarrollo. Una lectura desde la Constitución de Montecristi. 9(5): p. 1-36.

AGRAWAL, A. 1995. Dismantling the Divide Between Indigenous and Scientific Knowledge. Dev. Change.

ANDERSON, E.P. \& VEILLEUX, J.C. 2016. Cultural costs of tropical dams. Science. 352(6282):159.

ANDERSON, L.O., ARAGÃO, L.E.O.C., GLOOR, M., ARAI, E., ADAMI, M., SAATCHI, S., MALHI, Y., SHIMABUKURO, Y.E., BARLOW, J., BERENGUER, E. \& DUARTE, V. 2015. Disentangling the contribution of multiple land covers to fire-mediated carbon emissions in Amazonia during the 2010 drought. Global Biogeochem. Cycles 29:1739-1753.

ARAGÃO, L.E.O.C. et al. 2018. 21st Century drought-related fires counteract the decline of Amazon deforestation carbon emissions. Nat. Commun. $9(1): 1-12$.

ARAGÃO, L.E.O.C., MALHI, Y., ROMAN-CUESTA, R.M., SAATCHI, S., ANDERSON, L.O. \& SHIMABUKURO, Y.E. 2007. Spatial patterns and fire response of recent Amazonian droughts. Geophys. Res. Lett. 34(7):L07701.

ARMENTERAS, D., MURCIA, U., GONZÁLEZ, T.M., BARÓN, O.J. \& ARIAS,J.E. 2019. Scenarios of land use and land cover change for NW Amazonia: Impact on forest intactness. Global Ecology and Conservation. 17: e00567.

ARIMA, E.Y., BARRETO, P., ARAUJO, E. \& SOARES-FILHO, B. 2014. Public policies can reduce tropical deforestation: Lessons and challenges from Brazil. Land Use Policy. 41: 465-473.

ASSUNÇÃO, J.; GANDOUR, C. \& ROCHA, R. 2015. Deforestation slowdown in the Brazilian Amazon: prices or policies? Environ. Dev. Econ. 20: 697-722.

ATHAYDE, S., DUARTE, C.G., GALLARDO, A.L.C.F., MORETTO, E.M., SANGOI, L., DIBO, A.P.A., SIQUEIRA-GAY, J. \& SANCHEZ, L.E. 2019. Improving policies and instruments to address cumulative impacts of small hydropower in the Amazon. Energy Policy In Press(May):265-271.

BARBER, C.P., COCHRANE, M.A., SOUZA, C.M. \& LAURANCE, W.F. 2014. Roads, deforestation, and the mitigating effect of protected areas in the Amazon. Biol. Conserv. 177(2014):203-209.

BARLOW, J. et al. 2012. Quantifying the biodiversity value of tropical primary, secondary, and plantation forests. PNAS 104(47):1-256.

BOUCHER, D., ROQUEMORE, S. \& FITZHUGH, E. 2013. Brazil's success in reducing deforestation. Trop. Conserv. Sci. 6(3):426-445.

BRANDO, P.M., BALCH, J.K., NEPSTAD, D.C., MORTON, D.C., PUTZ, F.E., COE, M.T., SILVERIO, D., MACEDO, M.N., DAVIDSON, E.A., NOBREGA, C.C., ALENCAR, A. \& SOARES-FILHO, B.S. 2014. Abrupt increases in Amazonian tree mortality due to drought-fire interactions. Proc. Natl. Acad. Sci. 111(17):6347-6352.
BRANDO, P.M. et al. 2020. The gathering firestorm in southern Amazonia. Sci. Adv. 6:eaay1632.

BRAZIL, INPE. 2019. INPE consolida $7.536 \mathrm{~km}^{2}$ de desmatamento na Amazônia em 2018. Available at http://www.obt.inpe.br/OBT/noticias/inpe-consolida-7536-km2-de-desmatamento-na-amazonia-em-2018. Access 12 October 2019.

BROWN, D.S., BROWN, J.C. \& BROWN, C. 2016. Land occupations and deforestation in the Brazilian Amazon. Land use policy 54:331-338.

BURKHARD, B., KANDZIORA, M., HOU, Y. \& MÜLLER, F. 2014. Ecosystem service potentials, flows and demands-concepts for spatial localisation, indication and quantification. Landsc. Online 34(1):1-32.

CABRAl, A.I.R., SAITO, C., PEREIRA, H. \& LAQUES, A.E. 2018. Deforestation pattern dynamics in protected areas of the Brazilian Legal Amazon using remote sensing data. Appl. Geogr. 100(October):101-115.

CARVALHO, W.D., MUSTIN, K., HILÁRIO, R.R., VASCONCELOS, I.M., EILERS, V. \& FEARNSIDE, P.M. 2019. Deforestation control in the Brazilian Amazon: A conservation struggle being lost as agreements and regulations are subverted and bypassed. Perspect. Ecol. Conserv. 17(13): $122-130$

CHAN, K.M., GOULD, R.K. \& PASCUAL, U. 2018. Editorial overview: Relational values: what are they, and what's the fuss about? Curr. Opin. Environ. Sustain. 35A1-A7.

CHEN, L., YANG, X., CHEN, L. \& LI, L. 2015. Impact assessment of land use planning driving forces on environment. Environ. Impact Assess. Rev. 55:126-135.

COCHRANE, M. A. 2003. Fire science for rainforests. Nature 421(6926):913-9.

COLLEN, B., WHITTON, F., DYER, E.E., BAILLIE, J.E.M., CUMBERLIDGE, N., DARWALL, W.R.T., POLLOCK, C., RICHMAN, N.I., SOULSBY, A. \& BÖHM, M. 2014. R E S E A RC H Global patterns of freshwater species diversity, threat and endemism. 40-51.

CORREA, J.; DER HOFF, R. \& RAJÃO, R. 2019. Amazon Fund 10 Years Later: Lessons from the World's Largest REDD+ Program. Forests. 10(3): 272.

DE GROOT, R.S., WILSON, M.A. \& BOUMANS, R.M. 2002. A typology for the classification, description and valuation of ecosystem functions, goods and services. Ecol. Econ. 41(3):393-408.

DÍAZ, S. et al. 2015. The IPBES Conceptual Framework - connecting nature and people. Curr. Opin. Environ. Sustain. 141-16.

DÍAZ, S. et al. 2018. Assessing nature's contributions to people. Science. 359(6373):270-272.

FAMINOW, M.D. Spatial economics of local demand for cattle products in Amazon development. Agric. Ecosyst. Environ. 67:1-11.

FEARNSIDE, P.M. 2006. Dams in the Amazon: Belo Monte and Brazil's hydroelectric development of the Xingu River Basin. Environ. Manage. 38(1):16-27.

FEARNSIDE, P.M. 2015. Amazon dams and waterways: Brazil's Tapajós Basin plans. Ambio 44(5):426-439.

FEARSNIDE, P.M. 2008. The roles and movements of actors in the deforestation of Brazilian Amazonia. Ecol. Soc. 13(1):23.

FENG, Y., LU, D., MORAN, E., DUTRA, L., CALVI, M. \& DE OLIVEIRA, M. 2017. Examining Spatial Distribution and Dynamic Change of Urban Land Covers in the Brazilian Amazon Using Multitemporal Multisensor High Spatial Resolution Satellite Imagery. Remote Sens. 9(4):381.

FOLEY, J.A., ASNER, G.P., COSTA, M.H., COE, M.T., DEFRIES, R., GIBBS, H.K., HOWARD, E.A., OLSON, S., PATZ, J., RAMANKUTTY, N. \& SNYDER, P. 2007. Amazonia revealed: Forest degradation and loss of ecosystem goods and services in the Amazon Basin. Front. Ecol. Environ. 5(1):25-32.

GERWING, J.J. 2002. Degradation of forests through logging and fire in the eastern Brazilian Amazon. For. Ecol. Manage. 157(1-3):131-141.

GHAZOUL, J., BURIVALOVA, Z., GARCIA-ULLOA, J. \& KING, L.A. 2015. Conceptualizing Forest Degradation. Trends Ecol. Evol. 30(10):622-632.

GIBBS, H.K., RAUSCH, L., MUNGER, J., SCHELLY, I., MORTON, D.C., NOOJIPADY, P., SOARES-FILHO, B., BARRETO, P., MICOL, L. \& WALKER, N.F. 2015. Brazil's Soy Moratorium. Science (80-. ). 347(6220):377-378. 
HERRERA, D., PFAFF, A. \& ROBALINO, J. 2019. Impacts of protected areas vary with the level of government: Comparing avoided deforestation across agencies in the Brazilian Amazon. Proc. Natl. Acad. Sci. 116(30):1491614925 .

IPBES. 2018. The IPBES regional assessment report on biodiversity and ecosystem services for the Americas. Secretariat of the Intergovernmental Science-Policy Platform on Biodiversity and Ecosystem Services, Bonn, Germany.

JUNK, W.J., SOARES, M.G.M. \& BAYLEY, P.B. 2007. Freshwater fishes of the Amazon River basin: their biodiversity, fisheries, and habitats. Aquat. Ecosyst. Health Manag. 10(2):153-173.

KEEN, M., BROWN, V.A. \& DYBALL, R. 2012. Social learning in environmental management: Towards a sustainable future. London and New York: Earthscan

LATRUBESSE, E.M., ARIMA, E.Y., DUNNE, T., PARK, E., BAKER, V.R., HORTA, F.M., WIGHT, C., WITTMANN, F., ZUANON, J., BAKER, P.A., RIBAS, C.C., NORGAARD, R.B. \& FILIZOLA, N. 2017. Damming the rivers of the Amazon basin. Nat. Publ. Gr. 546(7658):363-369.

LAURANCE, W.F., COCHRANE, M.A., BERGEN, S., FEARNSIDE, P.M., DELAMÔNICA, P., BARBER, C., D'ANGELO, S. \& FERNANDES, T. 2001. The future of the Brazilian Amazon. Science. 291(5503):438-439.

LAURANCE, W.F., LOVEJOY, T.E., VASCONCELOS, H.L., BRUNA, E.M., DIDHAM, R.K., STOUFFER, P.C., GASCON, C., BIERREGAARD, R.O., LAURANCE, S.G. \& SAMPAIO, E. 2002. Ecosystem decay of Amazonian forest fragments: A 22-year investigation. Conserv. Biol. 16(3):605-618.

LEÃO, N., ALENCAR, C. \& VERÍSSIMO, A. 2008. Belém Sustentável 2007. Instituto do Homem e Meio Ambiente da Amazônia. Belém. p.28.

LI, G., LU, D., MORAN, E., CALVI, M.F., DUTRA, V., BATISTELLA, M., LI, G., LU, D., MORAN, E. \& CALVI, M.F. 2019. Examining deforestation and agropasture dynamics along the Brazilian TransAmazon Highway using multitemporal Landsat imagery. GIScience Remote Sens. 56(2):161-183.

LOBO, F.D.L., SOUZA-FILHO, P.W.M., NOVO, E., CARLOS, F.M. \& BARBOSA, C.C.F. 2018. Mapping Mining Areas in the Brazilian Amazon Using MSI / Sentinel-2 Imagery ( 2017 ). Remote Sens. 10(1178):1-14.

LUNDQUIST, C.J. et al. 2017. Visions for nature and nature's contributions to people for the 21 st century. NIWA Science and Technology Series Report No. 83, NIWA, New Zealand.

MAHAR, D.J. 1989. Government Policies and Deforestation in Brazil's Amazon Region. The International Bank for Reconstruction and Development, World Bank.

MAIA, H., HARGRAVE, J., GÓMEZ, J.J. \& RÖPER, M. 2011. Avaliação do Plano de Ação para Prevenção e Controle do Desmatamento na Amazônia Legal - PPCDAm. Available: < https://www.mma.gov.br/images/ arquivo/80120/Avaliacao\%20do\%20PPCDAm\%202007-2010.pdf> last access on $02 / 03 / 2020$ ).

MAPBIOMAS PROJECT. 2019. Mapbiomas - Collection 3.1 of the Annual Land Use Land Cover Maps of Brazil. Accessed on 05 August 2019. Available at http://mapbiomas.org/en

METZGER, J.P. et al. 2017. Best practice for the use of scenarios for restoration planning. Curr. Opin. Environ. Sustain. 2914-25.

MILLENNIUM ECOSYSTEM ASSESSMENT, 2003. Ecosystems and Human Well-Being: A Framework for Assessment. Report of the Conceptual Framework Working Group of the Millennium Ecosystem Assessment. Island Press, Washington. p.103. Available: <http://www. millenniumassessment.org/en/Framework.html>.

MINISTÉRIO DO MEIO AMBIENTE. 2016. Plano de Ação para Prevenção e Controle do Desmatamento na Amazônia Legal. Available: < https://www. mma.gov.br/informma/item/616-prevenção-e-controle-do-desmatamentona-amazônia > (last access on 02/03/2020).

MÜLLER-HANSEN, F., HEITZIG, J., DONGES, J.F., CARDOSO, M.F., DALLANORA, E.L., ANDRADE, P., KURTHS, J. \& THONICKE, K. 2019. Can Intensification of Cattle Ranching Reduce Deforestation in the Amazon? Insights From an Agent-based Social-Ecological Model. Ecol. Econ. 159:198-211.

NEPSTAD, D.C., TOHVER, I.M., DAVID, R., MOUTINHO, P. \& CARDINOT, G. 2007. Mortality of large trees and lianas following experimental drought in an amazon forest. Ecology 88(9):2259-2269.
NEPSTAD, D.C., VERSSIMO, A., ALENCAR, A., NOBRE, C., LIMA, E., LEFEBVRE, P., SCHLESINGER, P., POTTER, C., MOUTINHO, P., MENDOZA, E., COCHRANE, M. \& BROOKS, V. 1999. Largescale impoverishment of Amazonian forests by logging and fire. Nature 398(6727):505-508.

NEPSTAD, D. et al. 2014. Slowinf Amazon deforestation through public policy and interventions in beef and soy supply chains. Science. 344(6188):1118-1123.

OSTROM, E. 1990. Governing the commons: The evolution of institutions for collective action. New York: Cambridge University Press, Cambridge, UK.

PAHL-WOSTL, C., CRAPS, M., DEWULF, A., MOSTERT, E., TABARA, D. \& TAILLIEU, T. 2007. Research, part of a Special Feature on Social Learning in Water Resources Management Social Learning and Water Resources Management.

PERZ, S.G. 2002. Deforestation and land use in the Amazon. Univeristy Press of Florida, Gainesville.

PINHEIRO, T.F., ESCADA, M.I.S., VALERIANO, D.M., HOSTERT, P., GOLLNOW, F. \& MÜLLER, H. 2016. Forest degradation associated with logging frontier expansion in the Amazon: The BR-163 region in southwestern pará, Brazil. Earth Interact. 20(17):1-26.

PINSKY, V.C., kRUGLIANSKAS, I. \& VICTOR, D.G. 2019. Experimentalist governance in climate finance: the case of REDD + in Brazil. Climate Policy. 19(6): 725-738.

PÜTZ, S., GROENEVELD, J., HENLE, K., KNOGGE, C., MARTENSEN, A.C., METZ, M., METZGER, J.P., RIBEIRO, M.C., DE PAULA, M.D. \& HUTH, A. 2014. Long-term carbon loss in fragmented Neotropical forests. Nat. Commun. 5(5037):1-8.

RAJÃO, R. 2013. Representations and discourses: the role of local accounts and remote sensing in the formulation of Amazonia's environmental policy. Environ. Sci. Policy 3060-71.

RIBOT, J.C. \& PELUSO, N.L. 2009. A Theory of Access*. Rural Sociol. 68(2):153-181.

RODRIGUES-FILHO, S., VERBURG, R., BURSZTYN, M., LINDOSO, D., DEBORTOLI, N. \& VILHENA, A.M.G. 2015. Election-driven weakening of deforestation control in the Brazilian Amazon. Land use policy 43111-118.

ROSA, I.M.D., PURVES, D., SOUZA, C. \& EWERS, R.M. 2013. Predictive Modelling of Contagious Deforestation in the Brazilian Amazon. PLoS One 8(10):e77231.

ROSA, I.M.D. et al. 2017. Multiscale scenarios for nature futures. Nat. Ecol. Evol. 1(10):1416-1419.

RUIZ PEREZ, M. et al. 2004. Markets Drive the Specialization Strategies of Forest Peoples. Ecol. Soc. 9(2):4.

SCHMIDT, J.J. 2017. Social learning in the Anthropocene: Novel challenges, shadow networks, and ethical practices. J. Environ. Manage. 193:373-380.

SCHOOLENBERG, M. et al. 2018. Report on the workshop "Next Steps in Developing Nature Futures." Netherlands Environmental Assessment Agency, The Hague, Netherlands.

SILVAJUNIOR, C., ARAGÃO, L., FONSECA, M., ALMEIDA, C., VEDOVATO, L. \& ANDERSON, L. 2018. Deforestation-Induced Fragmentation Increases Forest Fire Occurrence in Central Brazilian Amazonia. Forests 9(6):305.

SIMMONS, C.S., WALKER, R.T., ARIMA, E.Y., ALDRICH, S.P. \& CALDAS, M.M. 2007. The amazon land war in the south of Pará. Ann. Assoc. Am. Geogr. 97(3):567-592.

SIMON, M.F. \& GARAGORRY, F.L. 2005. The expansion of agriculture in the Brazilian Amazon. Environ. Conserv. 32(3):203-212.

SIQUEIRA-GAY, J. \& SÁNCHEZ, L.E. 2019. Processes of land use change in two mining regions: implications for conservation in the Amazon forest. In Anais do XIX Simpósio Brasileiro de Sensoriamento Remoto, 2019, Santos. Anais eletrônicos Santos. 
SOARES-FILHO, B., ALENCAR, A., NEPSTAD, D., CERQUEIRA, G., DEL CARMEN VERA DIAZ, M., RIVERO, S., SOLÓRZANO, L. \& VOLL, E. 2004. Simulating the response of land-cover changes to road paving and governance along a major Amazon highway: The Santarém-Cuiabá corridor. Glob. Chang. Biol. 10(5):745-764.

SOARES-FILHO, B.S., CERQUEIRA, G.C. \& PENNACHIN, C.L. 2002. DINAMICA - A stochastic cellular automata model designed to simulate the landscape dynamics in an Amazonian colonization frontier. Ecol. Modell. 154(3):217-235.

SOARES-FILHO, B.S., NEPSTAD, D.C., CURRAN, L.M., CERQUEIRA, G.C., GARCIA, R.A., RAMOS, C.A., VOLL, E., MCDONALD, A., LEFEBVRE, P. \& SCHLESINGER, P. 2006. Modelling conservation in the Amazon basin. Nature 440(7083):520-523.

SOARES-FILHO, B., RAJÃO, R., MACEDO, M., CARNEIRO, A., COSTA, W., COE, M., RODRIGUES, H. \& ALENCAR, A. 2014. Cracking Brazil's Forest Code. Science (80). 344.

SONTER, L.J., HERRERA, D., BARRETT, D.J., GALFORD, G.L., MORAN, C.J. \& SOARES-FILHO, B.S. 2017. Mining drives extensive deforestation in the Brazilian Amazon. Nat. Commun. 8(1):1013.

SOTERRONI, A.C., RAMOS, F.M., MOSNIER, A., FARGIONE, J., ANDRADE, P.R., BAUMGARTEN, L., PIRKER, J., OBERSTEINER, M., KRAXNER, F., CÂMARA, G., CARVALHO, A.X.Y. \& POLASKY, S. 2019. Expanding the Soy Moratorium to Brazil's Cerrado. Sci. Adv. 5(7):eaav7336.

SOUZA-FILHO, P.W.M., DE SOUZA, E.B., SILVA JÚNIOR, R.O., NASCIMENTO, W.R., VERSIANI DE MENDONÇA, B.R., GUIMARÃES, J.T.F., DALL'AGNOL, R. \& SIQUEIRA, J.O. 2016. Four decades of land-cover, land-use and hydroclimatology changes in the Itacaiúnas River watershed, southeastern Amazon. J. Environ. Manage. 167175-184.

STRAND, J., SOARES-FILHO, B., COSTA, M.H., OLIVEIRA, U., RIBEIRO, S.C., PIRES, G.F., OLIVEIRA, A., RAJÃO, R., MAY, P., VAN DER HOFF, R., SIIKAMÄKI, J., DA MOTTA, R.S. \& TOMAN, M. 2018. Spatially explicit valuation of the Brazilian Amazon Forest's Ecosystem Services. Nat. Sustain. 1(11):657-664.

THE SPHERE PROJECT. 2011. Minimum Standards in Water Supply, Sanitation and Hygiene Promotion. In Humanitarian Charter and Minimum Standards in Disaster Response, The Sphere Project, Switzerland, p.79-137.
TRITSCH, I. \& LE TOURNEAU, F.M. 2016. Population densities and deforestation in the Brazilian Amazon: New insights on the current human settlement patterns. Appl. Geogr. 76163-172.

TUPIASSU, L., FADEL, L.P.S.L. \& GROS-DESORMEAUX. 2019. ICMS Ecológico e desmatamento nos municipios prioritários do estado do Pará. Revista Direito FGV. 15(3):e1928.

TURNER, B. L., R. H. MOSS, D. L. SKOLE, eds. 1993. Relating land use and global land-cover change: A proposal for an IGBP-HDP core project. Report from the IGBP-HDP Working Group on Land-Use/ Land-Cover Change. Joint publication of the International GeosphereBiosphere Programme (Report No. 24) and the Human Dimensions of Global Environmental Change Programme (Report No. 5). Available at: http://ciesin.org/docs/008-105/008-105.html. Last access: 22 September 2019

VERISSIMO, A. SOUZA-JUNIOR, C., STONE, S. \& UHL, C. 1998. Zoning of timber extraction in the Brazilian Amazon. Conservation Biology. 12(1):128-136.

WEST, T.A.P., BÖRNER, J. \& FEARNSIDE, P.M. 2019. Climatic Benefits From the

2006-2017 Avoided Deforestation in Amazonian Brazil. Front. For. Glob. Change 2(52): 1-11.

YANAI, A.M., NOGUEIRA, E.M., DE ALENCASTRO GRAÇA, P.M.L. \& FEARNSIDE, P.M. 2017. Deforestation and Carbon Stock Loss in Brazil's Amazonian Settlements. Environ. Manage. 59(3):393-409.

ZHANG, Y., LIU, L., WANG, J.Z., CHEN, J. \& LU, C.P. 2009. An index of river health for river plain network regions. IAHS-AISH Publ. 328112-121.

Received: $17 / 10 / 2019$

Revised: $20 / 03 / 2020$

Accepted: 24/03/2020

Published online: 11/05/2020 